\title{
Review \\ A Systematic Review of Technologies, Control Methods, and Optimization for Extended-Range Electric Vehicles
}

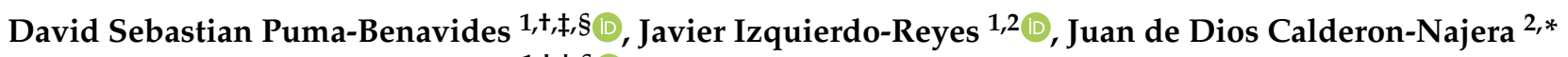 \\ and Ricardo A. Ramirez-Mendoza $1,+, \neq, \S(\mathbb{D}$ \\ 1 School of Engineering and Science, Tecnologico de Monterrey, Monterrey 64849, Mexico; \\ sebastian.puma@tec.mx (D.S.P.-B.); jizquierdo.reyes@tec.mx (J.I.-R.); ricardo.ramirez@tec.mx (R.A.R.-M.) \\ 2 Microsystems Technology Laboratories, Massachusetts Institute of Technology, Cambridge, MA 02139, USA \\ * Correspondence: jcalderon@tec.mx \\ + Current address: Toluca Campus, Av. Eduardo Monroy Cárdenas 2000 San Antonio Buenavista, \\ Toluca de Lerdo 50110, Mexico. \\ $\ddagger$ Current address: Mexico City Campus, Calle Puente 222, AMSA, Tlalpan, Mexico City 14380, Mexico. \\ $\S$ Current address: Mex and Monterrey City Campus, Av. Eugenio Garza Sada 2501 Sur, Tecnológico, \\ Monterrey 64849, Mexico.
}

check for updates

Citation: Puma-Benavides, D.S.; Izquierdo-Reyes, J.; Calderon-Najera, J.d.D.; Ramirez-Mendoza, R.A. A Systematic Review of Technologies, Control Methods, and Optimization for Extended-Range Electric Vehicles. Appl. Sci. 2021, 11, 7095. https:// doi.org/10.3390/app11157095

Academic Editors: Michele Roccotelli and Agostino Marcello Mangini

Received: 30 June 2021

Accepted: 21 July 2021

Published: 31 July 2021

Publisher's Note: MDPI stays neutral with regard to jurisdictional claims in published maps and institutional affiliations.

Copyright: (c) 2021 by the authors. Licensee MDPI, Basel, Switzerland. This article is an open access article distributed under the terms and conditions of the Creative Commons Attribution (CC BY) license (https:// creativecommons.org/licenses/by/ $4.0 /)$.

\begin{abstract}
For smart cities using clean energy, optimal energy management has made the development of electric vehicles more popular. However, the fear of range anxiety-that a vehicle has insufficient range to reach its destination-is slowing down the adoption of EVs. The integration of an auxiliary power unit (APU) can extend the range of a vehicle, making them more attractive to consumers. The increased interest in optimizing electric vehicles is generating research around range extenders. These days, many systems and configurations of extended-range electric vehicles (EREVs) have been proposed to recover energy. However, it is necessary to summarize all those efforts made by researchers and industry to find the optimal solution regarding range extenders. This paper analyzes the most relevant technologies that recover energy, the current topologies and configurations of EREVs, and the state-of-the-art in control methods used to manage energy. The analysis presented mainly focuses on finding maximum fuel economy, reducing emissions, minimizing the system's costs, and providing optimal driving performance. Our summary and evaluation of range extenders for electric vehicles seeks to guide researchers and automakers to generate new topologies and configurations for EVs with optimized range, improved functionality, and low emissions.
\end{abstract}

Keywords: extended range electric vehicle; technologies; optimization methods; EREV key components; level optimization

\section{Introduction}

Extended-range electric vehicles (EREVs), commonly known as series hybrid electric vehicles (Series-HEV), have better autonomy than electric vehicles (EV) without range extenders (REs). EREVs can go from one city to another or make long journeys in general. In recent years, EREVs have attracted considerable attention because of the necessity to improve autonomy using new and different technologies to generate extra energy for EVs. Today, fossil fuels meet the needs of the transportation sector to a significant extent, but bring on various adverse effects, such as air pollution, noise, and global warming. Compared to internal combustion engine vehicles (ICEVs), EREVs reduce emissions and are considered a favorable alternative [1,2]. EREVs, compared with EV, not only have the advantage of "zero fuel consumption and zero emissions"; they also effectively solve the problem of having an inadequate driving range due to power storage limitations in batteries [3]. This paper presents a systematic review on the subject of EREVs. First, an explanation of all the technologies used to extend the ranges of electric vehicles is presented and compared, considering the characteristics of each technology. The next 
stage reviews all the possible topologies for an EREV, analyzing the components and their interactions. The different control methods and their applications are also analyzed. The last part the analysis of how an EREV can be optimized. All the information is organized and presented in graphs and tables. As a contribution of our own, we propose a method for selecting the components of an EREV and designing its architecture based on the final application and use.

\section{Extended Range Electric Vehicle Technology}

A range extender (RE) is a small electricity generator (APU) which operates when needed as a solution to increase autonomy in EVs. The main components of the RE are the generator and internal or external combustion engine; the internal or external combustion engine is coupled to the generator in a series configuration. The primary function of the RE for an EV is to extend the vehicle's mileage. Operation of the range extender is initiated if the SOC (state of charge) of the EVs battery drops below a specified level. In this situation, the engine provides electricity by recharging the battery or directly driving the EV during travel and continues the vehicle's operation [4]. The difference in a plug-in hybrid electric vehicle (PHEV) is that the electric motor always propels the wheels. The engine acts as a generator to recharge the vehicle's battery when it depletes or as it propels the vehicle [5]. A series configuration is used as the main system, which is considered an APU. The system is connected to several subsystems, such as the generator, battery, electronic management system, and electric motor. The electric motor converts electrical energy from the battery to mechanical power. It propels the wheels while the APU generates electric energy to recharge the battery. Finally, the electronic management system controls all the systems for optimal functioning. The EREV has two operation modes: pure electric vehicle and extended-range mode. If the distance is short, the vehicle operates in pure electric vehicle mode without the RE. If the distance is long, the vehicle operates in extended-range electric vehicle mode.

The RE is off as long as there is sufficient energy in the battery for purely electric driving, and activated whenever the SOC drops below a certain level. The RE works until the desired SOC is achieved. The battery power manager gives this function. Figure 1 shows an EREV and energy flow configuration: (a) charge sustaining period and (b) depletion period. There are many technical and social challenges ahead for EVs coming up against the conventional ICEVs. Range anxiety is the most challenging problem facing EV drivers due to their shorter driving ranges compared to ICEVs. Range anxiety stems from the limited energy density in the current batteries $(0.565 \mathrm{MJ} / \mathrm{kg}$ for Li-ion battery), which is very low as compared to fossil fuel (43.48 MJ/ $\mathrm{kg})[6]$.

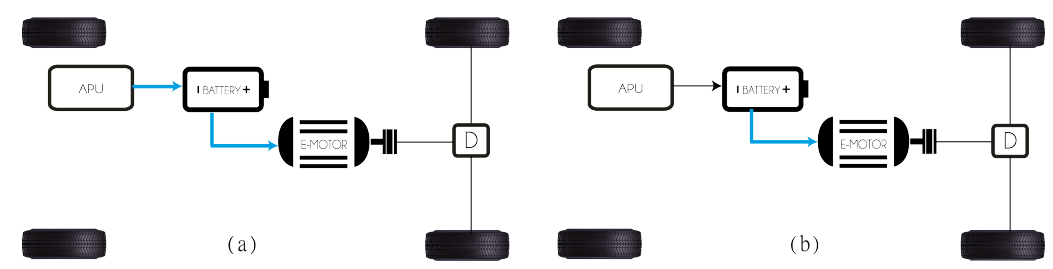

Figure 1. Configuration of an EREV and energy flow: (a) charge sustaining period; (b) depleting period.

\subsection{Technological Classification of EREV}

The electric propulsion system is the heart of an EREV. It consists of the motor drive, a transmission (optional) device, and wheels. There are three kinds of electric motors: direct or alternating current and in-wheel motors (also called wheel motors). The primary requirements of the EREV motor are summarized as follows:

1. High instant power and high power density.

2. High torque at low speeds for starting and climbing, and high power at high speeds for cruising. 
3. An extensive speed range including constant-torque and constant-power regions. In this case, the APU, when it is on, needs to operate in the same regions.

4. Fast torque response.

5. High efficiency over a large speed and torque ranges.

6. High reliability and robustness for various vehicle operating conditions.

7. Reasonable cost.

\subsubsection{Internal Combustion Engine Extended Range (ICE-ER)}

The range extender comprises a fuel tank, an internal combustion engine, and a permanent magnet synchronous generator [3,6-34], as shown in Figure 2. The structure is mechanically decoupled between the RE and the wheels of the EV. This configuration leads to a strong point whereby the output characteristics of the RE are not related to the vehicle's traction performance, and the output power only needs to meet the driving requirements. Therefore, one of the main objectives is to keep the RE operating in the high-efficiency region. The engine and the generator should be matched to achieve this common operating region [8]. As another solution, several studies have focused on energy harvesting using other types of fuels, such as natural gas [35] or diesel [36,37], to reduce pollution levels.

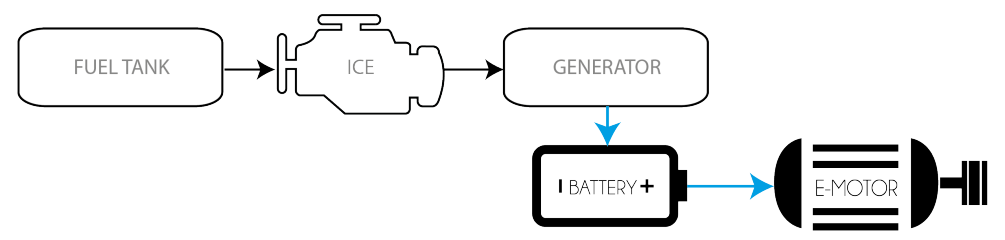

Figure 2. A diagram of the configuration of ICE-ER.

\subsubsection{Regenerative Shock Absorber Extended Range (RSA-ER)}

The shock absorber is a crucial component of the vehicle suspension and is combined with the suspension spring to filter vibrations when driving on rough roads. Typically, energy from vibrational sources is dissipated through hydraulic friction and heat via shock absorbers [38]. Currently, there are three categories for RSAs. The first type directly uses an electromagnetic method to generate electric power. The schemes of operation can be linear or rotary [39]. A linear electromagnetic RSA converts the kinetic energy of vertical oscillations into electricity by electromagnetic induction.

The second is the hydraulic RSA. This RSA can harvest energy by employing oscillatory motion to drive the power generator. Some studies reformed the existing hydraulic shock absorber and utilized the oil in the shock absorber to flow into a parallel oil circuit. They usually used the flowing fluid to drive a hydraulic motor connected in parallel to a DC/AC generator [40].

The third category is the mechanical RSA, which was developed quickly because of its greater efficiency and average power [38]. The general architecture of said RSA using supercapacitors, which are applied to extend the battery endurance, has four main parts: (1) the suspension vibration input module, (2) the transmission module, (3) the generator module, and (4) the power storage module, as shown in Figure 3.

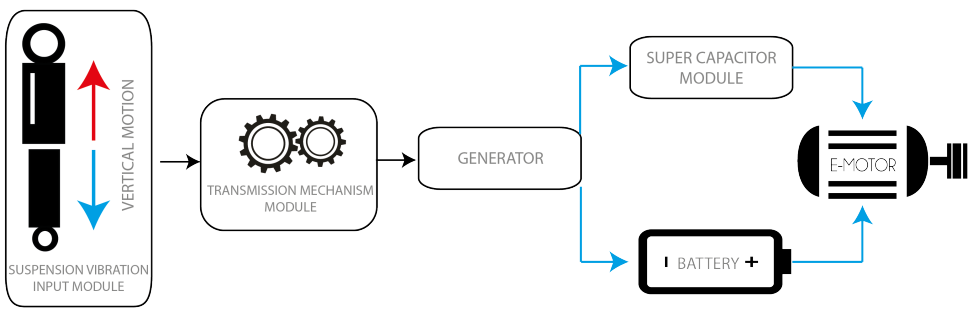

Figure 3. A diagram of the configuration of an RSA-ER. 


\subsubsection{Regenerative Braking Extended Range RB-ER}

The EV's motor can work as a generator under deceleration procedures, charging the battery and exerting regenerative braking torque on the axle simultaneously, as shown in Figure 4. A regenerative braking system (RBS) can capture the kinetic energy of an electric vehicle during the deceleration process, thereby improving the EV's energy efficiency. For an EV, friction and regenerative brakes generate brake torque, either separately or together [41]. In addition, the use of an adequate control strategy helps to reduce the loss rate; for example, the revised regenerative braking control strategy (RRBCS) can reduce inefficiency at the expense of slight braking energy recovery loss. Thus it positively affects prolonging the battery's life while ensuring braking safety and maximal recovery energy [42].

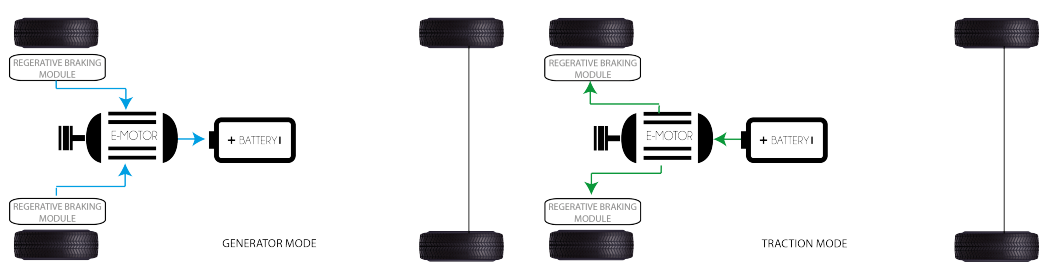

Figure 4. The configuration of an RB-ER. Energy flow: left generator mode and right traction mode.

An EV with automatic mechanical transmission (AMT) has higher transmission efficiency because it uses a composite braking process. The braking force of the motor varies according to the transmission gears at the same speed. Therefore, when the vehicle is braking, the transmission gear can be shifted reasonably according to the vehicle's condition. This mechanism improves the EV economy, since it allows the motor to work efficiently while recovering the braking energy to the maximum extent. An appropriate strategy can effectively improve the energy recovery rate and ensure braking safety and stability [43].

\subsubsection{Fuel Cell Extended Range (FC-ER)}

Fuel cells (FC) are electrochemical energy conversion devices that convert chemical energy directly into electrical energy and heat [44]. The electrochemical transformation is a chemical reaction of oxidant and reductant to produce electricity and water in stack output [45].

An anode, a cathode, and an electrolyte are the main components of an FC; water and electrical energy are the products. In the process, the anode supplies hydrogen, and the cathode terminal supplies oxygen [46]. During the reaction, hydrogen decomposes into positive protons and negative ions on the anode side. The resulting positive particles reach the cathode tip through the electrolyte, allowing only the positively charged particles to pass. The electrons, the negative ions at the end of the anode, tend to reunite with the positively charged particles and pass to the cathode side through an external circuit. This electron flow in the external circuit generates electricity. The electrons passing to the cathode side combine with positively charged particles and oxygen to produce pure water and heat, as shown in Figure 5 [1,47-53].

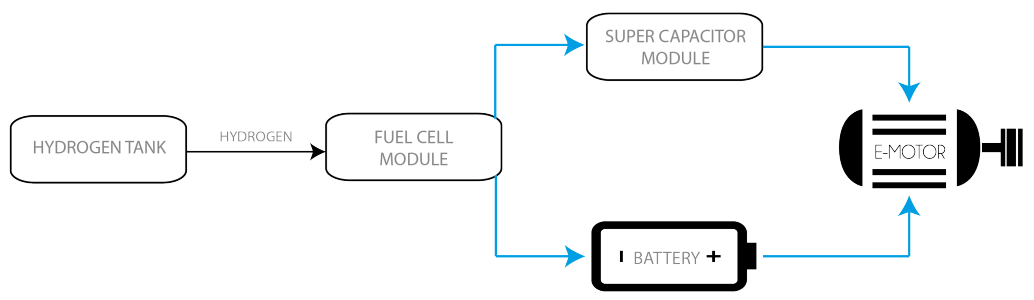

Figure 5. A diagram of the configuration of FC-ER. 


\subsubsection{Micro Gas Turbine Extended Range (MGT-ER)}

Microturbines (MGT) are small gas turbines with output power levels of 30 to $500 \mathrm{~kW}$ [54]. A MGT mainly consists of a single-stage radial compressor, a radial turbine section, and a recuperator. They usually use foil bearings (air bearings). The typical cycle of an MGT consists of four processes:

1. A radial compressor compresses the inlet air.

2. Air is pre-heated in the recuperator using heat from the turbine exhaust.

3. Heated air from the recuperator is mixed with fuel in the combustion chamber and burned.

4. Hot gas expands in turbine stages, and the gas's energy is converted into mechanical energy to drive the air-compressor and the drive equipment (usually generator).

Automakers claim that the gas turbine is the most efficient solution that is on its way. In particular, MGT can be an alternative to the ICE as a RE for EVs. The MGT produces less raw exhaust gaseous emissions, such as hydrocarbons and carbon monoxide, and has more static applications compared to the ICE. In addition, any MGT is lighter than the equivalent ICE, and it provides a potential reduction in the level of carbon dioxide produced [55-57]. Figure 6 shows the configuration of an MGT-ER connected to a generator and in series with a battery.

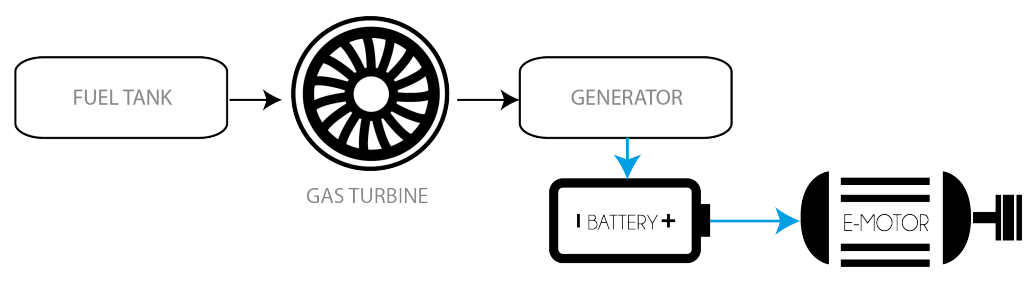

Figure 6. A diagram of the configuration of MGT-ER.

\subsubsection{Thermoacoustic Engine Extended Range (TAE-ER)}

Most vehicles waste nearly a third of their fuel's energy through the exhaust. Therefore, an efficient waste heat recovery process would undoubtedly improve fuel efficiency and reduce greenhouse gas emissions. Multiple waste heat recovery proposals exist. One of these is the thermoacoustic converter (TAC). The engine exhaust (hot side) and the coolant (cold side) produce a temperature differential that the TAC uses to produce electricity. Essentially, the TAC converts exhaust waste heat into electricity in two steps:

1. The exhaust heat is converted to acoustic energy (mechanical);

2. The acoustic energy is converted to electrical energy [58].

Three main stages illustrate how a TAE functions. The first is fuel burning in the combustion compartment, containing the combustion chamber blower and the combustion chamber. The second is the hot exhaust gases heading into the hot heat exchanger, transferring heat to the working fluids through a heat pipe. The third is the stack, which is the TAE's thermal module area and is surrounded by a hot and cold reservoir on each side, exchanging heat. The cold reservoir exchanges heat through the cold HEX with the ambient air $[59,60]$. Figure 7 shows a diagram with the main components in a TAE-ER.

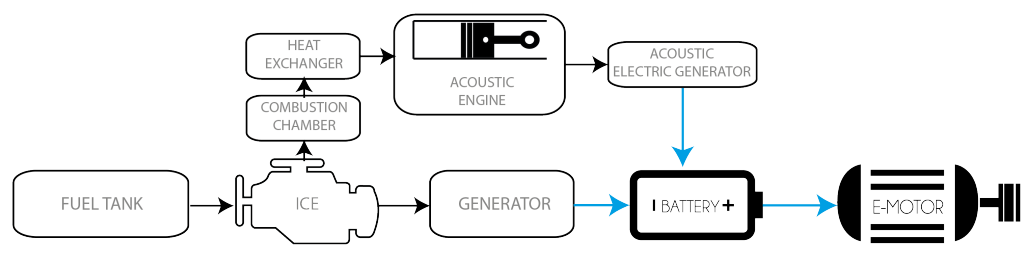

Figure 7. A diagram of the configuration of TAE-ER. 


\subsubsection{Flywheel Energy Storage Extended Range (FES-ER)}

A flywheel energy storage (FES) system has fast charge/discharge, is infinitely clean, and is highly efficient. The system consists of three energy storage components: a flywheel, a battery, and an ultra-capacitor. A flywheel is a rotating disk used as a mechanical energy storage device [61]. Two classes of materials are commonly used to fabricate the flyWheel, steel and composite materials. The difference is their rotational stress limitations. A composite-based flywheel can support higher speeds and rotational stress thresholds than a steel-based one. Therefore, composite materials can be used at high speeds (up to $100.00 \mathrm{rpm}$ ), whereas lower speeds (up to $10.000 \mathrm{rpm}$ ) apply to steel-based flywheels, which are heavier than the composite ones. The main limitation for the use of the composite material is its cost [62]. As a kind of short-term energy storage system, the FES system cannot be the primary power source of the vehicle. Therefore, a FES system with high power density is often used as an APU for a vehicle. The FES works while the vehicle brakes; it absorbs the RB energy. When the vehicle needs to accelerate, the FES system and the battery provide energy to the vehicle [31], as shown in Figure 8.
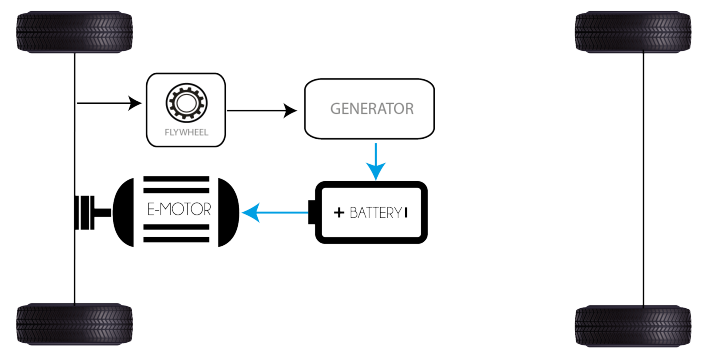

Figure 8. A diagram of the configuration of FES-ER.

\subsubsection{Solar Energy Storage Extended Range (SES-ER)}

Solar photovoltaic cells (PVCs) generate electricity by absorbing sunlight and converting it to electric current. Vehicle companies favor solar energy storage (SES) systems for their cleanliness, safety, and economic performance. Studying efficient and stable SES systems has become critical for many automobile enterprises [63]. A car using a PVC improves autonomy by about $10 \%$ when used in a city [64]. Ezzat et al. [65] proposed a novel comprehensive energy storage system for EREV. The energy storage system proposed consists of PVCs, an FC, and batteries. The results showed that the addition of solar cells to the energy storage system of EREV could improve energy efficiency, perfectly complementing a range extender. Figure 9 shows the configuration of an FES-ER.

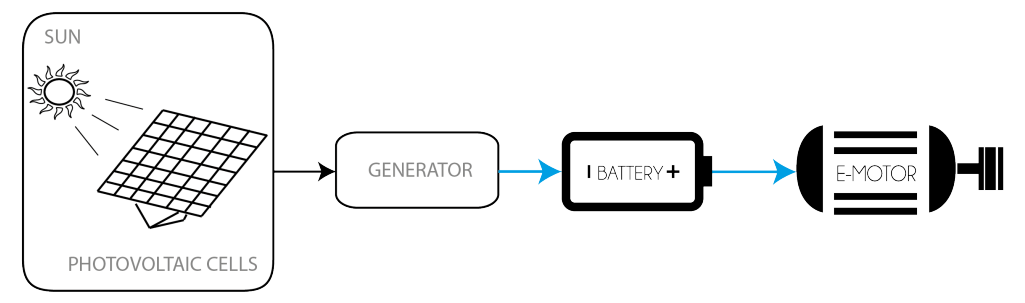

Figure 9. A diagram of the configuration of SES-ER.

\subsubsection{Rotatory Engine Extended Range (RE-ER)}

Rotary engines (REs) are small in size, and their high power output makes multiple electrification technology solutions possible via a shared packaging layout. The rotarypowered range extender takes advantage of their compatibility with gaseous fuels: it works by burning liquefied petroleum gas to provide a source of electricity. A rotary engine has only two moving parts: the rotor and the shaft are inherently balanced with no oscillating components and produce minimal vibrations [66]. Each crankshaft revolution produces 
one rotor revolution, a complete engine cycle in each of the four chambers, and four power strokes [67]. Figure 10 shows the configuration of RE-ER.

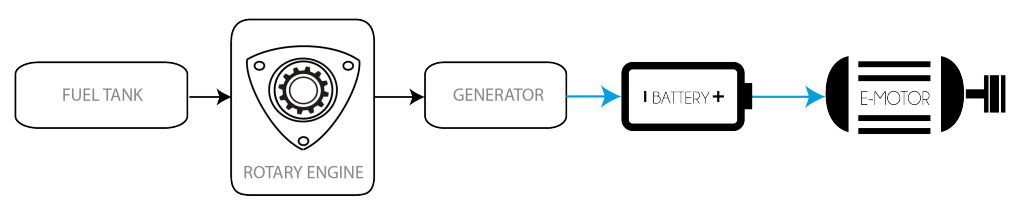

Figure 10. A diagram of the configuration of RE-ER.

Hydrogen combustion in a RE was carried out by Zambolov et al. [68], which complements the research about REs.

\subsubsection{Wind Turbine Extended Range (WT-ER)}

When a vehicle moves, it experiences wind resistance in two different forms-frictional drag and form drag. Frictional drag arises due to the viscosity of air, and form drag arises due to air pressure variation in the front and rear sides of the vehicle [69]. Suppose this wind energy is used to extract some power, not to create any component of force or thrust opposite the direction of the vehicle's propulsion. In that case, the energy can produce electricity to charge up the EV battery itself. [66,70,71] presented a conceptual design of harnessing wind's power to generate extra energy. Those designs can provide energy which could be stored or directly used to power electronic devices and vehicle instrumentation in a car or truck in movement. The use of wind energy in an EV can have different configurations, depending highly on the vehicle. One must not increase the drag coefficient to an extent that risks recovering the energy inefficiently. Figure 11 shows the configuration of WT-ER.

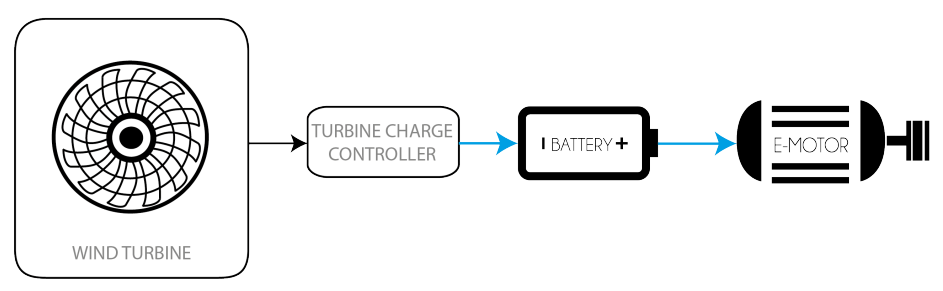

Figure 11. A diagram of the configuration of wind energy extended range.

\section{A Comparison of the Technology Used in EREVs}

When we design an extended range electric vehicle, we start by comparing the different technologies, analyzing their possible configurations, and analyzing the relationships among all their components.

The selection of the type of range extender at the time of vehicle design will depend on certain system characteristics. Thus, range extender systems are compared here. The criteria by which the systems are evaluated are as follows.

- System power;

- Amount of extra range;

- Global system efficiency;

- Emissions.

Vehicle concepts can have diverse sets of specifications. For example, the battery size and user profile determine the amount of time a range extender is used. This defines the importance of the efficiency. Furthermore, depending on the type of vehicle, the packing weight can be a more or less important criterion for choice of technology.

A brief overview of the collected information is presented in Table 1. It is clearly possible to identify that there are major differences between some of the concepts. 
Table 1. A comparison of the extended range systems.

\begin{tabular}{|c|c|c|c|c|}
\hline $\begin{array}{l}\text { Extended Range } \\
\text { System }\end{array}$ & System Power & Extra Range & Efficiency & Emissions \\
\hline ICE-ER & $\begin{array}{l}30 \mathrm{~kW} \mathrm{[12]} \\
35 \mathrm{~kW} \mathrm{[14]} \\
5.5 \mathrm{~kW} \mathrm{[35]} \\
111 \mathrm{~kW} \mathrm{[72]}\end{array}$ & $\begin{array}{c}232.79 \%[7] \\
430 \mathrm{~km} \mathrm{[12]} \\
51-139 \mathrm{~km} \mathrm{[35]} \\
380 \mathrm{~km} \mathrm{[73]} \\
330 \mathrm{~km} \mathrm{[74]} \\
676[72]\end{array}$ & $\begin{array}{c}20-40 \%[75,76] \\
31 \%[12]\end{array}$ & Low \\
\hline Fuel cell-ER & $\begin{array}{c}20 \mathrm{~kW} \mathrm{[77]} \\
85-83 \mathrm{~kW}[78] \\
1200 \mathrm{~W}[47] \\
25 \mathrm{~kW} \mathrm{[79]} \\
128 \mathrm{~kW}[80]\end{array}$ & $\begin{array}{c}500 \mathrm{~km}[77] \\
650 \mathrm{~km}[80] \\
665 \mathrm{~km}[81] \\
594 \mathrm{~km}[81] \\
1500 \mathrm{~km}[82]\end{array}$ & $\begin{array}{c}70 \%[77] \\
63.6-72.4 \%[83] \\
43 \%[47] \\
55.21 \%[79]\end{array}$ & No \\
\hline $\begin{array}{c}\text { Rotary } \\
\text { engine-ER }\end{array}$ & $\begin{array}{l}3.8 \mathrm{~kW}[84] \\
20 \mathrm{~kW}[85]\end{array}$ & $\begin{array}{c}80 \mathrm{~km}[85] \\
321 \mathrm{~km}[86]\end{array}$ & $\begin{array}{l}73 \%[87] \\
78 \%[84] \\
77 \%[85]\end{array}$ & Low \\
\hline RB-ER & $\begin{array}{c}14.8 \mathrm{~kW}[88] \\
55.75-82.66 \mathrm{~kJ}[89] \\
298.75 \mathrm{~kJ}[90]\end{array}$ & $\begin{array}{c}\text { 32.1-47.7\% of the } \\
\text { total recoverable } \\
\text { energy [89] } \\
1.18 \% \text { SOC improve [90] }\end{array}$ & $\begin{array}{c}79-94 \%[88] \\
30-60 \%[26] \\
47 \%[89]\end{array}$ & No \\
\hline MGT-ER & $\begin{array}{c}32 \mathrm{~kW}[91] \\
100 \mathrm{~kW}[92] \\
63.3 \mathrm{~kW}[93]\end{array}$ & 370 km [94] & $\begin{array}{c}47.2 \%[95] \\
28 \%[91] \\
30 \%[92] \\
35 \%[94] \\
38 \%[93]\end{array}$ & Low \\
\hline PVC-ER & 68.2-300 W [96] & 19.6 km [96] & $\begin{array}{c}91.2 \%[96] \\
20.2-23 \%[96]\end{array}$ & No \\
\hline WT-ER & $\begin{array}{c}2.64 \mathrm{~kW}[97] \\
0.1-1.1 \mathrm{~kW}[70]\end{array}$ & $\begin{array}{l}\text { add up to } 10 \% \text { [98] } \\
7.27 \mathrm{~km} \mathrm{[97]}\end{array}$ & $\begin{array}{c}75 \%[97] \\
75-90 \%[70]\end{array}$ & Low \\
\hline FES-ER & $\begin{array}{c}40 \mathrm{~kW} \text { to } 1.6 \mathrm{MW} \text { [99] } \\
60-101 \mathrm{~kW} \mathrm{[100]} \\
1-20 \mathrm{~kW}[101]\end{array}$ & $\begin{array}{c}50 \% \text { milage over }[100] \\
1.17 \% \text { milage over }[102]\end{array}$ & $\begin{array}{c}60 \%[100] \\
90-95 \%[103] \\
70-90 \%[104]\end{array}$ & No \\
\hline TAE-ER & $\begin{array}{c}710 \mathrm{~W}[105] \\
1029 \mathrm{~W}[106] \\
58 \mathrm{~W} \mathrm{[107]} \\
1.5 \mathrm{~kW}[108]\end{array}$ & $\begin{array}{l}80 \% \text { fuel consumtion } \\
\text { savings [59] }\end{array}$ & $\begin{array}{c}33.8-38.7 \%[60] \\
30 \%[105] \\
5.4 \%[106] \\
18 \%[78] \\
16 \%[108] \\
\end{array}$ & Low \\
\hline RSA-ER & $\begin{array}{c}\text { 8-40 W [100] } \\
0.74-0.78 \mathrm{~kW}[109] \\
19.2-67.5 \mathrm{~W}[110] \\
4.3 \mathrm{~W}[38]\end{array}$ & $\begin{array}{c}\text { Can power an } 8 \mathrm{~W} \text { lidar } \\
\text { for } 323 \text { days or a } 2 \mathrm{~W} \\
\text { camera for } 1292 \text { days [100] }\end{array}$ & $\begin{array}{c}70-80 \%[100] \\
71-84 \%[111] \\
33-63 \%[110] \\
87 \%[38] \\
16 \%[38]\end{array}$ & No \\
\hline
\end{tabular}


The increasing demand for extended driving range in electric vehicles is the most prominent factor driving the EREV market. As a result, the global EREV market is projected to reach more than 500,000 units and more than $\$ 1500$ million by 2026, at a compound annual growth rate (CAGR) of between $9.0 \%$ and $11.89 \%$ [112]. The Asia-Pacific market is estimated to reach more than $\$ 750$ million by 2026, with a CAGR of $8.1 \%$. North American market is estimated to reach more than $\$ 340$ million by 2026, at a significant CAGR of $10.6 \%[113,114]$.

Major industry participants are further investing a substantial amount into research and development processes to create advanced range extender products using various technologies. The top 10 automotive component manufacturers include the following: Magna offers a hydrogen fuel-cell platform as a range extender for battery electric vehicles. MAHLE offers an electric range extender engine for EVs to original equipment manufacturers (OEMs). The company's range extender engine offers an electric range extension of $65 \mathrm{~km}$. Rheinmetall offers heater/cooler modules for extending the driving ranges of electric buses. Plug Power is developing a fuel cell range extender electric vehicle that can extend the driving range by approximately $136 \mathrm{~km}$. AVL offers the entire range of powertrain systems for extended-range electric vehicles. The five other leading players are Ballard Power Systems, FEV, Delta Motorsport, Ceres Power, Nissan, General Motors, and BMW [112].

Many OEMs have integrated some of the RE technologies into mass production vehicles. Companies such as Chevrolet with its Volt model [72], BMW with its I3 and I3Rex models [73,74], and Honda with its Clarity model [115], have incorporated ICEs as range extenders. Brands such as Toyota with its Mirai model [80], and Hyundai with its Nexo model [81], have incorporated fuel cells as range extenders in light vehicles; NIKOLA MOTORS has included fuel cells in trucks, giving them autonomy for around $1500 \mathrm{~km}$ [82]. Mazda incorporated a rotary engine in its model Mazda 2 [86] and plans to incorporate the same technology in SUVs in the future. The heavy duty truck OEM MACK is using an MGT to extend the ranges of their vehicles. In its Karma model, Fisker placed photovoltaic cells over the entire roof of the vehicle to recover energy. It is worth mentioning that regenerative braking is used in almost all mass-produced light EVs and even in trucks such as the MACk LR model with a power output of $780 \mathrm{~kW}$ [116].

The market share of hybrid vehicles with alternative energy represents $0.7 \%$ of the total sales of all cars marketed until the middle of 2021. As of the end of 2020 , sales were $0.6 \%$ in North America. Referring to EVs with ICEs to extend their ranges, Honda's Clarity and Chevrolet's Volt have market shares of $4 \%$ and $0.1 \%$ respectively. Furthermore, concerning EVs with fuel cells to extend the range, there is Toyota's Mirai model and Hyundai's Nexo model with $3.1 \%$ and $0.3 \%[117,118]$.

\subsection{EREV Configuration}

The system for power transmission in an EREV includes an APU, an electric motor, and a battery. Other components complement the system, such as the DC-DC converter and an electronic controller, but these components do not define the vehicle's configuration. The electric motor is the main component that defines the configuration of an electric vehicle or extended-range electric vehicle. The configuration of the vehicle is determined by the position of the electric motor and by the technology. The electric motor can be in a longitudinal or lateral position, and it can be at the front or the rear of the vehicle. The electric motor transforms electrical energy into mechanical energy and transmits it to the wheels, but it can also have a gearbox and a mechanical differential. If the car has an electric motor for each wheel, or if the motors are inside the wheels, the differential system must be electronic.

An EV and its APU contribute three factors of major importance:

1. The traction force, which can be forward, backward, or four-wheel drive.

2. The position of the engine.

3. If it has a gearbox and the type of differential, mechanical or electronic. 
The type of configuration is studied and analyzed in order to optimize the topology better. The batteries are left aside and only are under consideration for the type of traction, the direction that the EV will have, the gearbox, and the final transmission ratio. The APU can be positioned regardless of the vehicle's configuration. The electric motor is the only one that provides power to the wheels.

\section{EREV Topological Configurations}

The EREV configuration combines the ICEV and EV configurations. It attempts to integrate the best parts of each one, and it is relatively flexible. This flexibility is due to several factors unique to the EV. An EREV works like an EV. First, the energy flow is mainly via flexible electrical wires rather than rigid and mechanical links, achieving distributed subsystems. Second, different EREV propulsion arrangements produce significant differences in system configuration. Third, different energy sources (such as auxiliary power units) have different characteristics and refueling systems. In general, the EREV consists of three major subsystems. Electric propulsion, which comprises an electronic controller, a power converter, an electric motor, mechanical transmission, a final drive, and driving wheels. An energy source, which involves the energy source, energy management unit, and charger. An auxiliary power unit, which consists of the generator, and depending on the technology, an ICE, a fuel cell, regenerative braking, regenerative shock absorbers, a flywheel, a thermoacoustic engine, photovoltaic cells, a gas turbine, a rotary engine, and a wind turbine/refueling unit. The energy management unit cooperates with the electronic controller to control regenerative energy and its energy recovery. It also works with the energy charger and monitors the usability of the energy source.

At present, there are many possible EREV configurations due to the variations in electric propulsion and energy sources. Thirteen alternatives focus on electric propulsion variations; some are in typical vehicles, and others are in high-performance vehicles.

(1) All-wheel drive (AWD; Figure 12a) is the first alternative, a direct extension of the existing ICEV adopting a longitudinal front engine. It consists of an electric motor, a gearbox, differential, an APU, battery, and a BMS connected to the electric motor; this configuration has two differentials to transmit the power to both axles.

Figure $12 \mathrm{~b}$ shows a typical configuration for pick-ups and high-performance sedan vehicles. The electric motor changes its orientation from longitudinal to cross-wise, maintaining a gearbox, two differentials, an APU, a battery, and a BMS. Figure 12c shows one electric motor in each axle; this configuration keeps a gearbox coupled with the motor. The gearbox can be single-gear or two-gear to multiply and divide torque and revolutions. Figure $12 \mathrm{~d}$ shows an electric motor for each wheel. The mechanical differential is replaced by an electronic differential that controls the speed differentiation of one wheel concerning the other. This type of configuration uses small, high-efficiency electric motors. Figure 12e shows a configuration with in-wheel motors. Again, one variant can have no gearbox. In this configuration, the electric motor has high efficiency and high velocity. The electric motor is connected directly to the wheel, and the other components are like those in the previous configurations. Figure $12 \mathrm{f}$ similarly uses in-wheel motors but simultaneously incorporates an electric differential, maintaining an APU, a battery, and a BMS; each wheel efficiently transmits power and reduces weight compared to other configurations.

(2) Front-wheel drive (FWD; Figure 12g). In this configuration, the electric motor changes from longitudinal to cross while maintaining the same components as the allwheel-drive configuration. The difference is that the mechanical power transmission is only to the front wheels, and it can have an electric motor for each wheel with or without a gearbox. Figure $12 \mathrm{~h}$ shows a configuration in which an electronic differential replaces the mechanical one. Figure 12i shows a similar configuration using electric motor in-wheel technology while keeping the battery, the BMS, and the APU. 

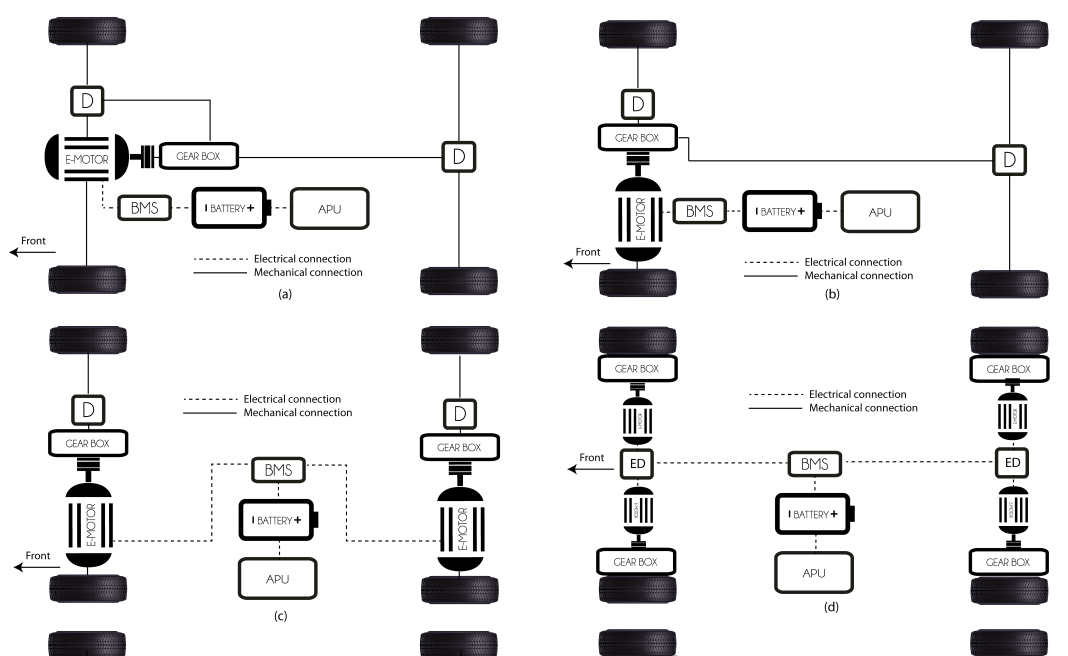
with the previous one is the position of the electric motor; it changes from longitudinal to cross; the rest of the components are the same. A configuration that improves the performance is having an electric motor in each wheel, with or without a gearbox, as shown in Figure 121. Figure 12m shows the last configuration, which uses the electric motor inwheel with electric differential. The selection of the configuration will depend on the size and application of the EREV. The primary criteria for selection are compactness, performance, weight, and cost.

Using driving cycles lets us know the emissions released and the energy consumption. However, due to the complexity and diversity of the vehicles, it is not easy to simulate a whole vehicle fleet using a physical approach [119], so we can use some software to estimate the emissions and energy consumption. Software such as MATLAB-Simulink, AVL Cruise, ADAMS, ANSYS, ADVISOR, ANSOFT, and MAPLESim can simulate driver/vehicle systems.

\subsection{Key Components of an EREV}

First, vehicle weight directly affects performance, especially the range and gradeability. Lightweight materials such as aluminum and composite materials for the body and chassis help with weight reduction. Second, achieving a low drag coefficient with the body design effectively reduces aerodynamic resistance, significantly extending the range of the EREV on highways or when cruising. The aerodynamic resistance can be reduced by tapering front and rear ends, and adopting a flat, covered, low-floor design. One can also optimize the airflow around the front and rear windows while using this flow to cool the batteries to minimize battery losses efficiently. Third, low rolling resistance tires effectively reduce running resistance at low and medium driving speeds and play an essential role in extending the range of EREVs in city driving. The design of an EREV requires considering the interactions of all the components that it may have. Figure 13 shows all the main components and the interactions that they may have with each other.

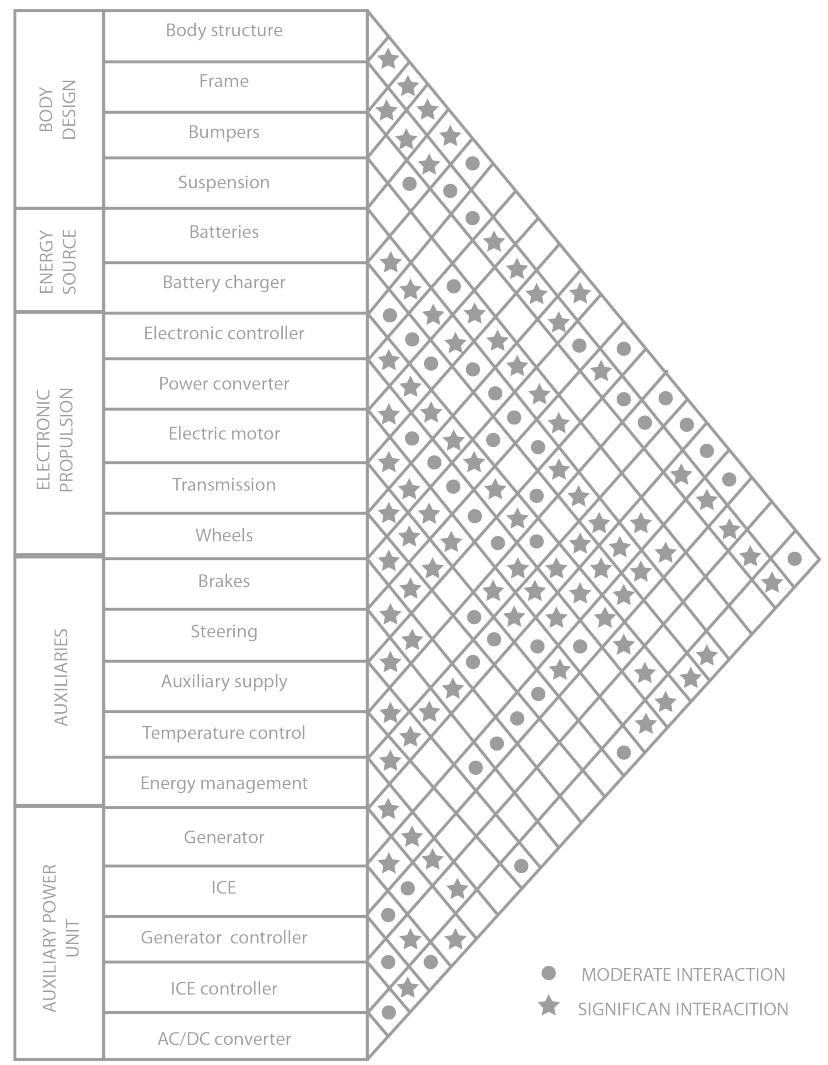

Figure 13. Key components and interactions. 


\section{Control and Management}

The control issue of power electronic interface converters plays a vital role in the efficient and safe operation of EREVs. There are many studies on the control of power flow and energy management. Table 2 shows studies about energy management methods. The control and management strategies are focused on (1) minimization of fuel consumption and loss of energy, (2) simplifying the structure, (3) increasing the maximum efficiency, and (4) ensuring robustness and satisfactory driving performance. Energy management: Adopting an intelligent energy management system (EMS) helps maximize onboard stored energy. Using sensor inputs, such as air temperature and currents and voltages for the motors and batteries, among other data, the EMS can perform the following functions:

1. Optimize the system's energy flow;

2. Predict the remaining energy and hence the residual driving cycle;

3. Turn on the APU to charge and improve the autonomy with a suitable control method;

4. Suggest more efficient driving behavior;

5. Direct energy regenerated from braking to receptive energy sources such as the batteries;

6. Modulate temperature control as a response to external climate;

7. Propose battery charging;

8. Analyze the operation history of the energy source, especially the battery;

9. Diagnose any incorrect behavior or defective components of the energy source, or malfunctions of any component.

Table 2. A summary of control methods and strategies for EREVs.

\begin{tabular}{|c|c|c|c|c|c|}
\hline $\begin{array}{c}\text { Control } \\
\text { Methods/Strategy }\end{array}$ & Author & $\begin{array}{l}\text { Controlled } \\
\text { System }\end{array}$ & Technology & Purpose & Application \\
\hline $\begin{array}{c}\text { Constant power control } \\
\text { strategy }\end{array}$ & [3] & BMS & ER-ICE & $\begin{array}{l}\text { The lowest permissible } \\
\text { level of SOC after the } \\
\text { drive charge the vehicle }\end{array}$ & $\begin{array}{c}\text { Charging Management } \\
\text { Arterial Roads }\end{array}$ \\
\hline $\begin{array}{l}\text { A power follower control } \\
\text { strategy }\end{array}$ & [3] & BMS & ER-ICE & $\begin{array}{l}\text { The lowest permissible } \\
\text { level of SOC after the } \\
\text { drive charge the vehicle }\end{array}$ & $\begin{array}{c}\text { Charging Management } \\
\text { Express Way }\end{array}$ \\
\hline $\begin{array}{l}\text { Proportional resonant } \\
\text { control strategy }\end{array}$ & [8] & Generator & ER-ICE & $\begin{array}{l}\text { To maintain the } \\
\text { efficient region } \\
\text { of the generator }\end{array}$ & Generate more energy \\
\hline $\begin{array}{l}\text { Partial power following } \\
\text { control strategy }\end{array}$ & [8] & ICE & ER-ICE & $\begin{array}{l}\text { To maintain the } \\
\text { efficient region to } \\
\text { operate the ICE }\end{array}$ & Reduce fuel consumption \\
\hline $\begin{array}{c}\text { A control strategy based } \\
\text { on Pontryagins } \\
\text { Minimum Principle } \\
\text { (PMP) }\end{array}$ & [9] & ICE & ER-ICE & $\begin{array}{l}\text { Monitors the current } \\
\text { SOC of the battery }\end{array}$ & $\begin{array}{l}\text { Minimizes the energy } \\
\text { consumed during driving }\end{array}$ \\
\hline $\begin{array}{c}\text { Predictive control-based } \\
\text { energy management }\end{array}$ & [90] & Fuel Cells & ER-FC & Forecasted speed & $\begin{array}{l}\text { Minimize hydrogen } \\
\text { consumption }\end{array}$ \\
\hline $\begin{array}{c}\text { Regenerative Braking } \\
\text { control strategy (RRBCS) }\end{array}$ & [28] & $\begin{array}{l}\text { Regenerative } \\
\text { braking }\end{array}$ & ER-RB & $\begin{array}{l}\text { The better capacity of } \\
\text { the regenerative braking } \\
\text { energy consider slip } \\
\text { ratio of the tire }\end{array}$ & $\begin{array}{l}\text { Coordinate regenerative } \\
\text { braking torque and } \\
\text { mechanical friction to } \\
\text { maximize energy recovery } \\
\text { and to ensure the braking } \\
\text { efficiency }\end{array}$ \\
\hline
\end{tabular}


Table 2. Cont.

\begin{tabular}{|c|c|c|c|c|c|}
\hline $\begin{array}{c}\text { Control } \\
\text { Methods/Strategy }\end{array}$ & Author & $\begin{array}{l}\text { Controlled } \\
\text { System }\end{array}$ & Technology & Purpose & Application \\
\hline $\begin{array}{c}\text { A normal control } \\
\text { strategy based on a } \\
\text { state of charge (SOC) }\end{array}$ & [12] & ICE & ER-ICE & $\begin{array}{l}\text { Monitors the battery } \\
\text { state of charge (SOC) }\end{array}$ & Reduce $\mathrm{CO}_{2}$ emissions \\
\hline $\begin{array}{l}\text { Automatic Mechanical } \\
\text { Transmission (AMT) } \\
\text { Shift control strategy }\end{array}$ & [43] & $\begin{array}{l}\text { Regenerative } \\
\text { braking }\end{array}$ & ER-RB & $\begin{array}{l}\text { Identify the braking } \\
\text { intention and } \\
\text { transmission shifts } \\
\text { correctly }\end{array}$ & $\begin{array}{l}\text { Improve the braking energy } \\
\text { recovery rate, and ensure } \\
\text { the braking safety a stability }\end{array}$ \\
\hline $\begin{array}{l}\text { Start-stop control } \\
\text { strategy }\end{array}$ & [33] & $\begin{array}{c}\text { ICE- } \\
\text { Generator }\end{array}$ & ER-ICE & $\begin{array}{l}\text { Reduce the start-stop } \\
\text { times and running time }\end{array}$ & Fuel economy \\
\hline $\begin{array}{c}\text { Adaptive power } \\
\text { management strategy PMS }\end{array}$ & [18] & ICE & ER-ICE & $\begin{array}{l}\text { Asses the battery SOC } \\
\text { and vehicle speed }\end{array}$ & $\begin{array}{l}\text { Improve energy savings, the } \\
\text { fuel, and electrical } \\
\text { consumption }\end{array}$ \\
\hline $\begin{array}{l}\text { Method of quantitative } \\
\text { estimation }\end{array}$ & [120] & Generator & ER-ICE & $\begin{array}{l}\text { Optimize the design } \\
\text { parameters aiming at } \\
\text { the maximum efficiency } \\
\text { in the continuos rated }\end{array}$ & $\begin{array}{l}\text { Find maximum torque per } \\
\text { ampere }\end{array}$ \\
\hline $\begin{array}{l}\text { Charge-deplete-charge- } \\
\text { sustain (CDCS) strategy }\end{array}$ & [15] & $\begin{array}{l}\text { ICE- } \\
\text { Generator }\end{array}$ & ER-ICE & $\begin{array}{l}\text { Asses the battery SOC } \\
\text { and vehicle speed }\end{array}$ & $\begin{array}{l}\text { Energy efficiency, reduce } \\
\text { energy consumption and } \\
\text { reduce costs of operation }\end{array}$ \\
\hline $\begin{array}{l}\text { Thermal management } \\
\text { system to battery } \\
\text { cooling strategy }\end{array}$ & [22] & Battery & ER-ICE & $\begin{array}{l}\text { Quantify the heat } \\
\text { generation sources and } \\
\text { accurately predicting } \\
\text { cell temperatures }\end{array}$ & $\begin{array}{l}\text { Improve longevity, safety, } \\
\text { and overall performance }\end{array}$ \\
\hline $\begin{array}{l}\text { A data driving behavior } \\
\text { predictive control } \\
\text { strategy }\end{array}$ & [23] & $\begin{array}{l}\text { Driving } \\
\text { behavior }\end{array}$ & ER-ICE & $\begin{array}{l}\text { Predict the EV power } \\
\text { requests and optimize } \\
\text { their control inputs }\end{array}$ & $\begin{array}{l}\text { Improving the driving range } \\
\text { and battery life while } \\
\text { maintaining thermal comfort } \\
\text { for the passengers }\end{array}$ \\
\hline $\begin{array}{l}\text { Mixed-integer } \\
\text { convex program }\end{array}$ & [37] & Powertrain & ER-ICE & $\begin{array}{l}\text { Formulate an economic } \\
\text { optimization }\end{array}$ & $\begin{array}{c}\text { All the quantities to minimize } \\
\text { are expressed as a monetary } \\
\text { variable }\end{array}$ \\
\hline $\begin{array}{l}\text { The convex optimal } \\
\text { control problem }\end{array}$ & [36] & Powertrain & ER-ICE & $\begin{array}{l}\text { Optimization over the } \\
\text { entire driving cycle is } \\
\text { computed offline }\end{array}$ & $\begin{array}{l}\text { Achieve the best possible } \\
\text { energy consumption. }\end{array}$ \\
\hline $\begin{array}{l}\text { The optimal operation } \\
\text { curve control strategy }\end{array}$ & [29] & ICE & ER-ICE & $\begin{array}{l}\text { Research and control } \\
\text { the vehicle required } \\
\text { torque }\end{array}$ & $\begin{array}{l}\text { Control the power allocation } \\
\text { of APU and batteries to } \\
\text { reduce fuel consumption and } \\
\text { obtain good fuel economy }\end{array}$ \\
\hline $\begin{array}{l}\text { Multi-objective } \\
\text { hierarchical prediction } \\
\text { energy management } \\
\text { strategy }\end{array}$ & [52] & Fuel cells & ER-FC & $\begin{array}{l}\text { Propose a Global state of } \\
\text { charge rapid planning } \\
\text { method based only on } \\
\text { the expected driving } \\
\text { distance }\end{array}$ & $\begin{array}{c}\text { Achieve optimal fuel cell life } \\
\text { economy and energy } \\
\text { consumption economy }\end{array}$ \\
\hline $\begin{array}{l}\text { A novel energy-aware } \\
\text { velocity planning }\end{array}$ & [32] & ICE & ER-ICE & $\begin{array}{l}\text { Propose energy-aware } \\
\text { velocity planning }\end{array}$ & $\begin{array}{l}\text { Improve electric vehicle fuel } \\
\text { efficiency }\end{array}$ \\
\hline $\begin{array}{l}\text { Pseudospectral optimal } \\
\text { control }\end{array}$ & [34] & APU & ER-ICE & $\begin{array}{l}\text { Maintain engine speed } \\
\text { constant is better for the } \\
\text { dynamic characteristics } \\
\text { of APU }\end{array}$ & $\begin{array}{l}\text { Different limits of the APU } \\
\text { power changing rate } \\
\text { significantly influence the } \\
\text { fuel consumption }\end{array}$ \\
\hline $\begin{array}{l}\text { Model predictive } \\
\text { control }\end{array}$ & {$[121,122]$} & Powertrain & ER-ICE & $\begin{array}{l}\text { Propose a computationally } \\
\text { tractable model prediction } \\
\text { control (MPC) }\end{array}$ & $\begin{array}{l}\text { Prediction horizon so that } \\
\text { energy consumption is } \\
\text { minimized }\end{array}$ \\
\hline
\end{tabular}




\section{System Optimization}

As mentioned before, EREVs have complex architectures that contain multidisciplinary technologies. Since the EREV performance can be affected by many multidisciplinary, interrelated factors, computer simulations are the most critical technology with which to optimize performance and reduction costs. Additionally, EREV simulations can help manufactures to minimize prototyping costs and rapidly evaluate their concepts. Since an EREV's system consists of various subsystems clustered together by mechanical, electrical, control, and thermal links, the simulation should be a parameterized mixed-signal one. Hence, optimization is at the system level, at which there are many tradeoffs among various subsystem criteria. The preferred system criteria generally involve numerous iterative processes. In summary, the system-level simulation and optimization of EREVs should consider the following key issues.

1. As the interactions among various subsystems significantly affect the performances of EREVs, the significance of those interactions should be analyzed and taken into account.

2. The model's accuracy is usually correlated with the model's complexity, but the latter may run counter to usability, tradeoffs among the accuracy, complexity, usability, and simulation time should be considered.

3. The system voltage generally causes contradictory issues for EREV design. For example, the battery weight (higher voltage requires more battery modules in series, and hence more weight for the battery case). Similarly, motor drive voltage and current ratings, auxiliary power unit range, energy generated, acceleration performance, driving range, and safety should be optimized at the system level.

4. The adoption of multiple energy sources helps to increase the driving range. For the EREV case, the APU should be optimized based on the vehicle's performance and cost requirements.

\subsection{Controller Optimization for Plant}

In an EREV, a plant could be an ICE, an electric motor, or a battery. Different strategies can optimize the plant and its controller: sequential, iterative, bi-level, and simultaneous strategies [123]. Sequential optimization often leads to non-optimal system designs due to plant/controller optimization coupling. Iterative plant/controller optimization strategies attempt to improve the initial design by first improving the plant design without compromising control performance and optimizing the controller design without compromising plant performance. In a bi-level plant/controller optimization strategy, two nested optimization loops are used. The outer loop optimizes the scalar-substituted objective function by changing only the plant's design. The role of the inner loop is to generate the optimal controller for each plant selected by the outer loop. The simultaneous strategy can be mathematically and computationally challenging for several reasons. The simultaneous plant/controller optimization problem is a hybrid static/variational problem. Even when the plant and controller optimization subproblems are convex, the collaborative problem is not guaranteed to be convex. Figure 14 shows the strategies for plant/controller optimization.

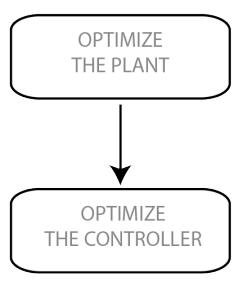

SEQUENTIAL

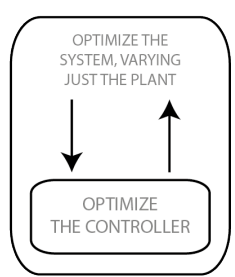

BI-LEVEL

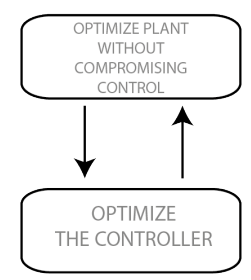

ITERATIVE

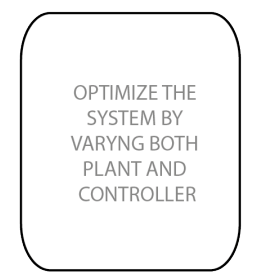

SIMULTANEOS

Figure 14. Strategies for plant/controller optimization. 


\subsection{Multidisciplinary Optimization}

It is necessary to capture the effects of each energy domain on the dynamics of the other domains to optimize a system. For example, when analyzing extended-range electric vehicles, the generator and internal combustion engine coupling should be optimized to provide the energy needed to charge the batteries and increase the vehicle's autonomy.

EREV power trains reduce design space for the remainder of the physical system and increase the complexity of the control. The coupling (dependency) among the parameters of the physical system (e.g., topology) and the control parameters transforms the problem into a multi-level problem, as depicted in Figure 14. If solved sequentially, it is by definition sub-optimal [124]. Therefore, the physical system and the control should be designed in an integrated manner to obtain an optimal system. Due to the oversized dimensions of the design space, computer simulations of dynamical systems have become more important as a preliminary step to building prototypes, e.g., for different architectures and component sizes. Computer simulations significantly speed up the control synthesis of a given design and topology. However, even with computer systems, finding the optimal vehicle design that provides the best control performance is typically intractable. It is not feasible (cost or time-wise), given design space, to build all possible vehicles and evaluate which configuration and parameters provide the best control performance.

\subsection{Optimal Control}

There is tight integration between the physical design and an element's control from a dynamics perspective. A sequential design process is often used to design the physical system, which is followed by control-system design [125]. In EREVs, we need to know the functions of all components and their interactions to generate the best possible control systems. The simulations are important because they predict system behavior given the specifications provided. However, a simulation can also be used for the inverse task: identifying system specifications that produce the desired behavior.

\subsection{Size Optimization}

It is essential to optimize the sizing of propulsion system components without reducing performance to reduce the manufacturing costs and emissions associated with transport platforms. In a conventional vehicle, the size of the ICE is directly associated with the maximum power required for the vehicle. Similarly, in the case of pure electric vehicles, the range depends on the size of the battery. In general, it is the energy rather than the power that conditions the sizing of the batteries. There is not total freedom of design in either platform, because a single energy source powers the vehicle in both cases.

Extended-range electric vehicles have at least one degree of design freedom, that is, the sizes of their energy sources, because more than one energy source is integrated. The sizing of an EREV platform consists specifically of defining the size requirements in terms of power and/or energy. Then, the sizes of the energy sources and the vehicle's power requirements implicitly define the sizes of the power converters that make up the propulsion system. The choice of component size significantly affects vehicle's performance in terms of power availability, energy efficiency, manufacturing costs, and component life. Figure 15 shows the strategies for plant/controller optimization. 


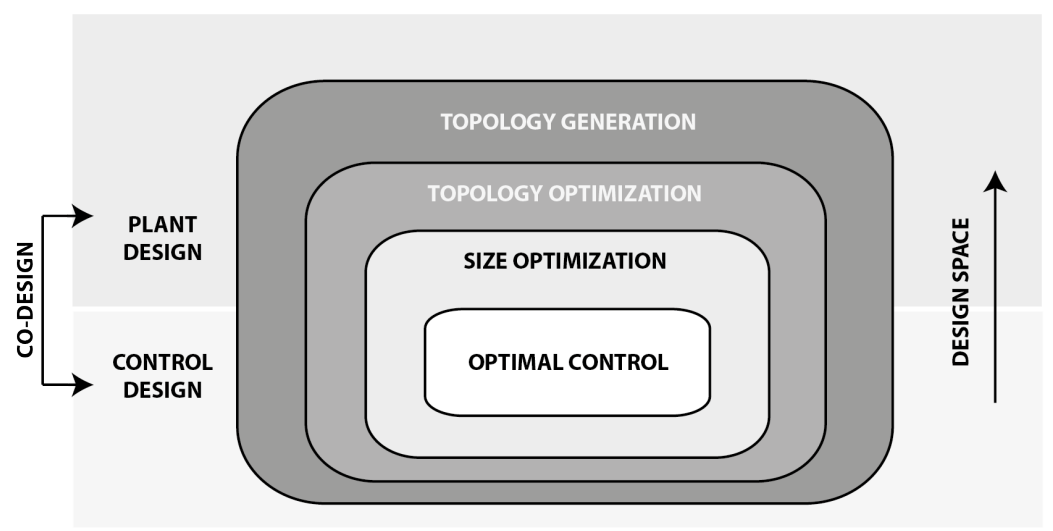

Figure 15. Optimization levels of an EREV.

\section{The Process of Designing an EREV}

Here we present a guide for designing an extended-range electric vehicle in general terms.

Once the kinds of technology have been analyzed and compared, after knowing the possible configurations and the interactions of the components, a conceptual design of an extended range electric vehicle can be generated. However, first, we must define the type of vehicle we are going to design. There are three types that cover the vast majority of vehicles, and they are compacts, pick ups, and trucks.

As a second step, depending on the type of vehicle we want to design, we select the type of traction that this may have, which varies depending on the type of vehicle; the three main types are FWD, RWD, and AWD.

As a third step, we define the technology of the electric motor that the EV will have and its position for its configuration. In-wheel motors are commonly used in compact vehicles.

As a fourth step, we have the selection of the range extender system. We can make our selection under certain criteria, and we are helped by Figure 16, where we compare these technologies. For practice, we define two selection criteria: the amount of power and the emissions. Large vehicles need high levels of autonomy; small vehicles can have medium or low levels of autonomy. Our selection criteria are the extra range needed, a high, medium, or low amount; and the space and weight that can be sacrificed.

As a fifth step, the controller selection (independent or general controllers) will depend on the control strategy to use; we can consult Table 1.

We can also optimize the controller selection (see Section 5) using the strategies shown, and our components' sizes.

Then, we will finally have our extended range electric vehicle, which should have ideal performance, optimal control, and optimized components. All steps are shown in Figure 16. 
Extended Range Electric Vehicle

configuration, ER selecction,

control and optimization

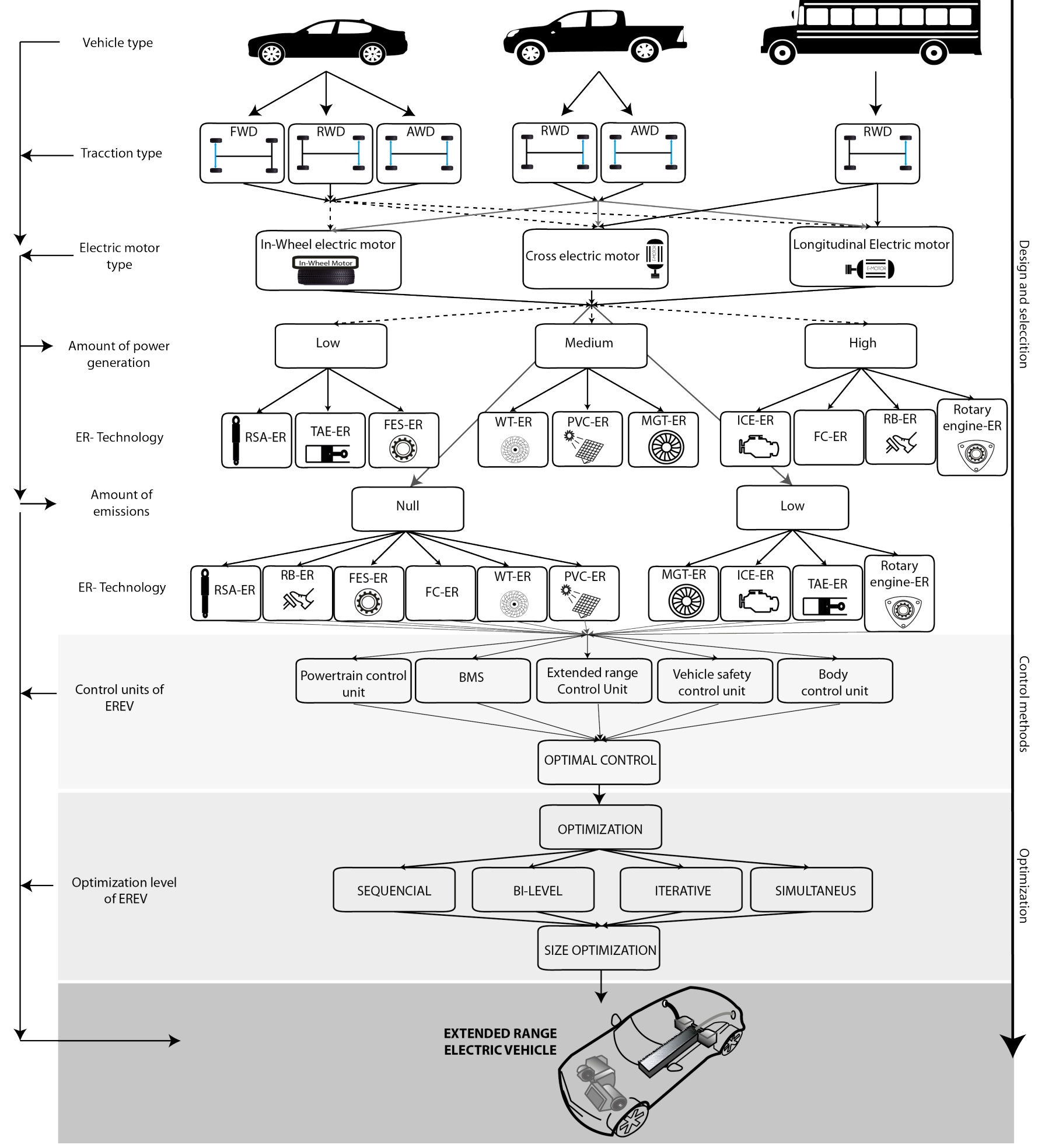

Figure 16. The process of designing an EREV. 


\section{Discussion}

This paper reviewed the current technologies, control methods, optimization methods, and design methods for EREV vehicles, including the architecture, key components and their interactions with each other, the sizing of components, and methods to find the optimal system-level design. Although at first glance, there seem many different configurations, the most commonly used have an electric motor in the central position. However, the use of an in-wheel motor is typical if the vehicle has high performance. The central aspect to consider with the technologies used to recover energy and increase autonomy is the cost of implementing them. Some technologies are more economical and easier to control. Additionally, the fuel or resource cost for the range extender to work is a limiting factor for integration and profitability; it helps the electric vehicle concerning autonomy. All the technologies presented in this work aid electric vehicles. Depending on the budget that each researcher or research center has, it can implement and carry out tests to verify and optimize the implementation of the selected technologies. Currently, the combustion engine is the most common technology used to increase autonomy. That is why most researchers seek to reduce ICEs' fuel consumption to increase energy efficiency and recover energy. By analyzing the literature, we can conclude that the use of optimization methods will depend on the scope of the research, but usually involves finding the most efficient configuration of all components, thereby solving different optimization layers for design. These could be further used in more extended coordination methods to include the selection of topologies and technologies. For instance, these extended coordination methods might include: (i) simultaneous topology and sizing design, alternating with controller design; (ii) controller design nested for simultaneous topology and sizing, (iii) topology alternating with sizing or control; or (iv) simultaneous topology, sizing, and control design. We have presented a guide for determining critical components and the interactions between them in order to design a new topology and optimize all levels depending on the technologies used.

To substantially reduce the computational burden, the introduction of approximations of the original problem should shorten the driving cycle used for design, or one should use parallel computing. Driving cycles used as input for the control (energy management strategy) or any simulation should be short, realistic, and representative of realistic driving types. In some cases, it is necessary to create a personalized driving cycle to analyze the behavior of the extended-range electric vehicle concerning energy consumption, range, and emissions. A problem that remains open is how to address multiple topologies with a large variety in terms of component types and quantities in a more intuitive way. In addition, optimization problems and automatic construction of topologies spur on the development of control algorithms that automatically handle various topologies. Optimization objectives can be defined to include, in addition to fuel, also cost, emissions, and performance aspects to solve the design problem at the system level, to find a competitive EREV configuration for the market. User-friendly methodologies are needed to help developers so that the industry at large achieves the best designs early in HEV development.

Author Contributions: Conceptualization, D.S.P.-B. and J.d.D.C.-N.; writing-original draft preparation, D.S.P.-B.; writing-review and editing, J.I.-R. and R.A.R.-M.; supervision, J.d.D.C.-N. and R.A.R.-M. All authors have read and agreed to the published version of the manuscript.

Funding: This research was funded by Tecnologico de Monterrey, grant number a01366354, and by the National Council for Science and Technology (CONACYT), grant number 862836.

Institutional Review Board Statement: Not applicable.

Informed Consent Statement: Not applicable.

Data Availability Statement: Not applicable.

Acknowledgments: We thank the CIMA lab, Toluca Campus, for the valuable collaboration.

Conflicts of Interest: The authors declare no conflict of interest. 


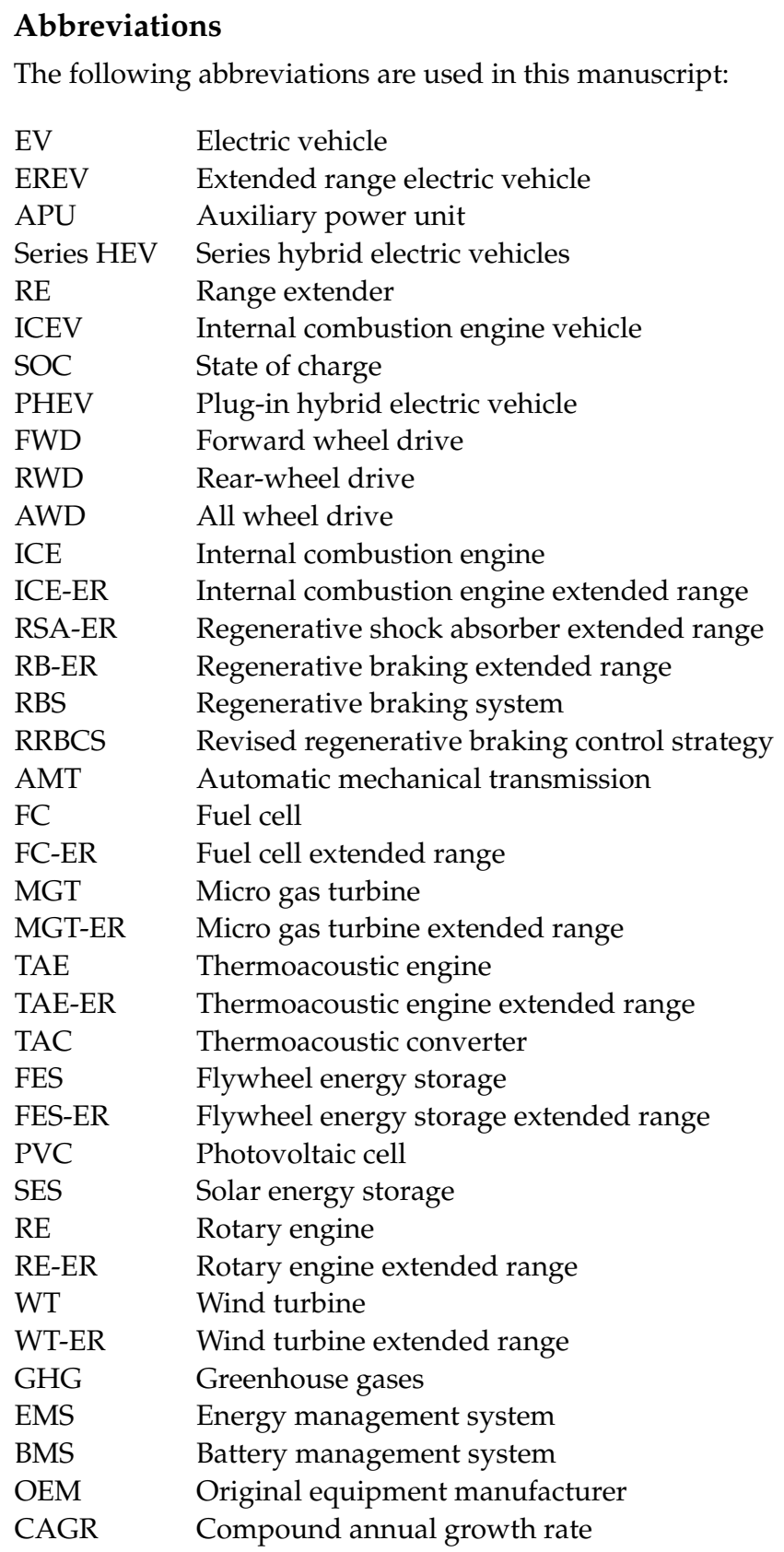

\section{References}

1. İnci, M.; Büyük, M.; Demir, M.H.; İlbey, G. A review and research on fuel cell electric vehicles: Topologies, power electronic converters, energy management methods, technical challenges, marketing and future aspects. Renew. Sustain. Energy Rev. 2021, 137, 110648. [CrossRef]

2. Lou, G.; Ma, H.; Fan, T.; Chan, H.K. Impact of the dual-credit policy on improvements in fuel economy and the production of internal combustion engine vehicles. Resour. Conserv. Recycl. 2020, 156, 104712. [CrossRef]

3. Song, W.; Zhang, X.; Tian, Y.; Xi, L.h. A charging management-based intelligent control strategy for extended-range electric vehicles. J. Zhejiang Univ. Sci. A 2016, 17, 903-910. [CrossRef]

4. Tate, E.D.; Harpster, M.O.; Savagian, P.J. The Electrification of the Automobile: From Conventional Hybrid, to Plug-in Hybrids, to Extended-Range Electric Vehicles. SAE Int. J. Passeng. Cars-Electron. Electr. Syst. 2008, 1, 2008-01-0458. [CrossRef]

5. Song, K.; Zhang, J.; Zhang, T. Design and Development of a pluggable PEMFC extended Range Electric Vehicle. In Proceedings of the 2011 Second International Conference on Mechanic Automation and Control Engineering, Inner Mongolia, China, 15-17 July 2011; pp. 1144-1147. [CrossRef]

6. Xian, T.F.; Soon, C.M.; Rajoo, S.; Romagnoli, A. A parametric study: The impact of components sizing on range extended electric vehicle's driving range. In Proceedings of the 2016 Asian Conference on Energy, Power and Transportation Electrification (ACEPT), Singapore, 25-27 October 2016; pp. 1-6. [CrossRef] 
7. Wahono, B.; Nur, A.; Santoso, W.B.; Praptijanto, A. A comparison study of range-extended engines for electric vehicle based on vehicle simulator. J. Mech. Eng. Sci. 2016, 10, 1803-1816. [CrossRef]

8. Wang, X.; Lv, H.; Sun, Q.; Mi, Y.; Gao, P. A Proportional Resonant Control Strategy for Efficiency Improvement in Extended Range Electric Vehicles. Energies 2017, 10, 204. [CrossRef]

9. Lee, W.; Jeoung, H.; Park, D.; Kim, N. An Adaptive Concept of PMP-Based Control for Saving Operating Costs of Extended-Range Electric Vehicles. IEEE Trans. Veh. Technol. 2019, 68, 11505-11512. [CrossRef]

10. Tang, T.Q.; Chen, L.; Yang, S.C.; Shang, H.Y. An extended car-following model with consideration of the electric vehicle's driving range. Phys. A Stat. Mech. Appl. 2015, 430, 148-155. [CrossRef]

11. Xu, X.; Lv, M.; Chen, Z.; Ji, W.; Gao, R. Analysis of electric vehicle extended range misalignment based on rigid-flexible dynamics. IOP Conf. Ser. Earth Environ. Sci. 2017, 61, 012018. [CrossRef]

12. Hall, J.; Marlok, H.; Bassett, M.; Warth, M. Analysis of Real World Data from a Range Extended Electric Vehicle Demonstrator. SAE Int. J. Altern. Powertrains 2014, 4, 2887. [CrossRef]

13. Dost, P.; Spichartz, P.; Sourkounis, C. Charging behaviour of users utilising battery electric vehicles and extended range electric vehicles within the scope of a field test. In Proceedings of the 2015 International Conference on Renewable Energy Research and Applications (ICRERA), Palermo, Italy, 22-25 November 2015; Volume 54, pp. 1162-1167. [CrossRef]

14. Figueroa-García, J.; López-Santana, E.; Villa-Ramírez, J.; Ferro-Escobar, R. Applied Computer Sciences in Engineering. Commun. Comput. Inf. Sci. 2017, 742, 65-71. [CrossRef]

15. Du, J.; Chen, J.; Song, Z.; Gao, M.; Ouyang, M. Design method of a power management strategy for variable battery capacities range-extended electric vehicles to improve energy efficiency and cost-effectiveness. Energy 2017, 121, 32-42. [CrossRef]

16. Guan, J.C.; Chen, B.C.; Wu, Y.Y. Design of an Adaptive Power Management Strategy for Range Extended Electric Vehicles. Energies 2019, 12, 1610. [CrossRef]

17. Shi, L.; Guo, Y.; Xiao, D.; Han, Z.; Zhou, X. Design, optimization, and study of a rare-earth permanent-magnet generator with new consequent-pole rotor for extended-range electric vehicle. IEEJ Trans. Electr. Electron. Eng. 2019, 14, 917-923. [CrossRef]

18. Du, J.; Chen, J.; Gao, M.; Wang, J. Energy Efficiency Oriented Design Method of Power Management Strategy for Range-Extended Electric Vehicles. Math. Probl. Eng. 2016, 2016, 1-9. [CrossRef]

19. Sneha Angeline, P.; Newlin Rajkumar, M. Evolution of electric vehicle and its future scope. Mater. Today Proc. 2020, 33, 3930-3936. [CrossRef]

20. Lijewski, P.; Kozak, M.; Fuć, P.; Rymaniak, Ł.; Ziółkowski, A. Exhaust emissions generated under actual operating conditions from a hybrid vehicle and an electric one fitted with a range extender. Transp. Res. Part D Transp. Environ. 2020, 78, 102183. [CrossRef]

21. Guo, R.; Cao, C.; Mi, Y.; Huang, Y. Experimental investigation of the noise, vibration and harshness performances of a range-extended electric vehicle. Proc. Inst. Mech. Eng. Part D J. Automob. Eng. 2016, 230, 650-663. [CrossRef]

22. Ramotar, L.; Rohrauer, G.L.; Filion, R.; MacDonald, K. Experimental verification of a thermal equivalent circuit dynamic model on an extended range electric vehicle battery pack. J. Power Sources 2017, 343, 383-394. [CrossRef]

23. Vatanparvar, K.; Faezi, S.; Burago, I.; Levorato, M.; Al Faruque, M.A. Extended Range Electric Vehicle with Driving Behavior Estimation in Energy Management. IEEE Trans. Smart Grid 2019, 10, 2959-2968. [CrossRef]

24. Yan, X.; Fleming, J.; Lot, R. Extending the range of Plug-in Hybrid Electric Vehicles by CVT transmission optimal management. Energy Procedia 2018, 151, 17-22. [CrossRef]

25. Kim, T.Y.; Lee, S.H. Combustion and emission characteristics of wood pyrolysis oil-butanol blended fuels in a DI diesel engine. Int. J. Automot. Technol. 2015, 16, 903-912. [CrossRef]

26. Wu, D.; Feng, L. On-Off Control of Range Extender in Extended-Range Electric Vehicle using Bird Swarm Intelligence. Electronics 2019, 8, 1223. [CrossRef]

27. Lee, G.S.; Kim, D.H.; Han, J.H.; Hwang, M.H.; Cha, H.R. Optimal Operating Point Determination Method Design for RangeExtended Electric Vehicles Based on Real Driving Tests. Energies 2019, 12, 845. [CrossRef]

28. Liu, H.; Lei, Y.; Fu, Y.; Li, X. Parameter matching and optimization for power system of range-extended electric vehicle based on requirements. Proc. Inst. Mech. Eng. Part D J. Automob. Eng. 2020, 234, 3316-3328. [CrossRef]

29. Jiang, Y. Parameters Optimization for Extended-range Electric Vehicle Based on Improved Chaotic Particle Swarm Optimization. Int. J. Grid Distrib. Comput. 2016, 9, 1-10. [CrossRef]

30. Kopczyński, A.; Krawczyk, P.; Lasocki, J. Parameters selection of extended-range electric vehicle supplied with alternative fuel. E3S Web Conf. 2018, 44, 00073. [CrossRef]

31. Ren, G.; Shan, S.; Ma, G.; Shang, X.; Zhu, S.; Zhang, Q.; Yang, T. Review of energy storage technologies for extended range electric vehicle. J. Appl. Sci. Eng. 2019, 22, 69-82. [CrossRef]

32. Baek, D.; Chang, N. Runtime Power Management of Battery Electric Vehicles for Extended Range With Consideration of Driving Time. IEEE Trans. Very Large Scale Integr. (VLSI) Syst. 2019, 27, 549-559. [CrossRef]

33. Zhao, J.b.; Han, B.y.; Bei, S.y. Start-Stop Moment Optimization of Range Extender and Control Strategy Design for Extended -Range Electric Vehicle. IOP Conf. Ser. Mater. Sci. Eng. 2017, 241, 012025. [CrossRef]

34. Li, J.; Wang, Y.; Chen, J.; Zhang, X. Study on energy management strategy and dynamic modeling for auxiliary power units in range-extended electric vehicles. Appl. Energy 2017, 194, 363-375. [CrossRef]

35. Chambon, P.; Curran, S.; Huff, S.; Love, L.; Post, B.; Wagner, R.; Jackson, R.; Green, J. Development of a range-extended electric vehicle powertrain for an integrated energy systems research printed utility vehicle. Appl. Energy 2017, 191, 99-110. [CrossRef] 
36. Pozzato, G.; Formentin, S.; Panzani, G.; Savaresi, S. Least Costly Energy Management for Extended-Range Electric Vehicles with Noise Emissions Characterization. IFAC-PapersOnLine 2019, 52, 586-591. [CrossRef]

37. Pozzato, G.; Formentin, S.; Panzani, G.; Savaresi, S.M. Least costly energy management for extended-range electric vehicles: An economic optimization framework. Eur. J. Control 2020, 56, 218-230. [CrossRef]

38. Zhang, Z.; Zhang, X.; Chen, W.; Rasim, Y.; Salman, W.; Pan, H.; Yuan, Y.; Wang, C. A high-efficiency energy regenerative shock absorber using supercapacitors for renewable energy applications in range extended electric vehicle. Appl. Energy 2016, 178, 177-188; Corrigendum in 2019, 254, 113634. [CrossRef]

39. Satpute, N.V.; Singh, S.; Sawant, S.M. Energy Harvesting Shock Absorber with Electromagnetic and Fluid Damping. Adv. Mech. Eng. 2015, 6, 693592-693592. [CrossRef]

40. Zhang, Y.; Zhang, X.; Zhan, M.; Guo, K.; Zhao, F.; Liu, Z. Study on a novel hydraulic pumping regenerative suspension for vehicles. J. Frankl. Inst. 2015, 352, 485-499. [CrossRef]

41. Qiu, C.; Wang, G.; Meng, M.; Shen, Y. A novel control strategy of regenerative braking system for electric vehicles under safety critical driving situations. Energy 2018, 149, 329-340. [CrossRef]

42. Liu, H.; Lei, Y.; Fu, Y.; Li, X. An Optimal Slip Ratio-Based Revised Regenerative Braking Control Strategy of Range-Extended Electric Vehicle. Energies 2020, 13, 1526. [CrossRef]

43. Zhao, X.; Xu, S.; Ye, Y.; Yu, M.; Wang, G. Composite braking AMT shift strategy for extended-range heavy commercial electric vehicle based on LHMM/ANFIS braking intention identification. Clust. Comput. 2019, 22, 8513-8528. [CrossRef]

44. Aygen, M.S.; İnci, M. Zero-sequence current injection based power flow control strategy for grid inverter interfaced renewable energy systems. Energy Sources Part Recover. Util. Environ. Eff. 2020, 1-22. [CrossRef]

45. Ozden, A.; Shahgaldi, S.; Li, X.; Hamdullahpur, F. A review of gas diffusion layers for proton exchange membrane fuel cells-With a focus on characteristics, characterization techniques, materials and designs. Prog. Energy Combust. Sci. 2019, 74, 50-102. [CrossRef]

46. İnci, M. Active/reactive energy control scheme for grid-connected fuel cell system with local inductive loads. Energy 2020, 197, 117191. [CrossRef]

47. Zhou, Y.; Li, H.; Ravey, A.; Péra, M.C. An integrated predictive energy management for light-duty range-extended plug-in fuel cell electric vehicle. J. Power Sources 2020, 451, 227780. [CrossRef]

48. Chu, Y.; Wu, Y.; Chen, J.; Zheng, S.; Wang, Z. Design of energy and materials for ammonia-based extended-range electric vehicles. Energy Procedia 2019, 158, 3064-3069. [CrossRef]

49. Dimitrova, Z.; Maréchal, F. Environomic design for electric vehicles with an integrated solid oxide fuel cell (SOFC) unit as a range extender. Renew. Energy 2017, 112, 124-142. [CrossRef]

50. Wu, X.L.; Xu, Y.W.; Zhao, D.q.; Zhong, X.B.; Li, D.; Jiang, J.; Deng, Z.; Fu, X.; Li, X. Extended-range electric vehicle-oriented thermoelectric surge control of a solid oxide fuel cell system. Appl. Energy 2020, 263, 114628. [CrossRef]

51. Karaoğlan, M.U.; Kuralay, N.S.; Colpan, C.O. Investigation of the effects of battery types and power management algorithms on drive cycle simulation for a range-extended electric vehicle powertrain. Int. J. Green Energy 2019, 16, 1-11. [CrossRef]

52. Liu, Y.; Li, J.; Chen, Z.; Qin, D.; Zhang, Y. Research on a multi-objective hierarchical prediction energy management strategy for range extended fuel cell vehicles. J. Power Sources 2019, 429, 55-66. [CrossRef]

53. Geng, C.; Jin, X.; Zhang, X. Simulation research on a novel control strategy for fuel cell extended-range vehicles. Int. J. Hydrogen Energy 2019, 44, 408-420. [CrossRef]

54. Almasi, A. Bright future of micro-turbines: Nuclear emergency cooling and miniature generator. Aust. J. Mech. Eng. 2013, 11, 169-175. [CrossRef]

55. Karvountzis-Kontakiotis, A.; Andwari, A.M.; Pesyridis, A.; Russo, S.; Tuccillo, R.; Esfahanian, V. Application of Micro Gas Turbine in Range-Extended Electric Vehicles. Energy 2018, 147, 351-361. [CrossRef]

56. Bou Nader, W.S.; Mansour, C.J.; Nemer, M.G. Optimization of a Brayton external combustion gas-turbine system for extended range electric vehicles. Energy 2018, 150, 745-758. [CrossRef]

57. Reine, A.; Bou Nader, W. Fuel consumption potential of different external combustion gas-turbine thermodynamic configurations for extended range electric vehicles. Energy 2019, 175, 900-913. [CrossRef]

58. Sahoo, D.; Kotrba, A.; Steiner, T.; Swift, G. Waste Heat Recovery for Light-Duty Truck Application Using ThermoAcoustic Converter Technology. SAE Int. J. Engines 2017, 10, 0153. [CrossRef]

59. Nader, W.B.; Chamoun, J.; Dumand, C. Optimization of the thermodynamic configurations of a thermoacoustic engine auxiliary power unit for range extended hybrid electric vehicles. Energy 2020, 195. [CrossRef]

60. Bou Nader, W.; Chamoun, J.; Dumand, C. Thermoacoustic engine as waste heat recovery system on extended range hybrid electric vehicles. Energy Convers. Manag. 2020, 215, 112912. [CrossRef]

61. Arani, A.K.; Karami, H.; Gharehpetian, G.; Hejazi, M. Review of Flywheel Energy Storage Systems structures and applications in power systems and microgrids. Renew. Sustain. Energy Rev. 2017, 69, 9-18. [CrossRef]

62. Itani, K.; De Bernardinis, A.; Khatir, Z.; Jammal, A. Comparative analysis of two hybrid energy storage systems used in a two front wheel driven electric vehicle during extreme start-up and regenerative braking operations. Energy Convers. Manag. 2017, 144, 69-87. [CrossRef]

63. ElNozahy, M.; Salama, M. Studying the feasibility of charging plug-in hybrid electric vehicles using photovoltaic electricity in residential distribution systems. Electr. Power Syst. Res. 2014, 110, 133-143. [CrossRef] 
64. Keshri, R.; Bertoluzzo, M.; Buja, G. Integration of a Photovoltaic Panel with an Electric City Car. Electr. Power Compon. Syst. 2014, 42, 481-495. [CrossRef]

65. Ezzat, M.; Dincer, I. Development, analysis and assessment of a fuel cell and solar photovoltaic system powered vehicle. Energy Convers. Manag. 2016, 129, 284-292. [CrossRef]

66. Zahir Hussain, M.; Anbalagan, R.; Jayabalakrishnan, D.; Naga Muruga, D.; Prabhahar, M.; Bhaskar, K.; Sendilvelan, S. Charging of car battery in electric vehicle by using wind energy. Mater. Today Proc. 2020. [CrossRef]

67. King, P. The Development of the Szorenyi Four-Chamber Rotary Engine. In Proceedings of the SAE International Powertrains, Fuels and Lubricants Meeting, Heidelberg, Germany, 17-19 September 2018. [CrossRef]

68. Zambalov, S.D.; Yakovlev, I.A.; Maznoy, A.S. Effect of multiple fuel injection strategies on mixture formation and combustion in a hydrogen-fueled rotary range extender for battery electric vehicles. Energy Convers. Manag. 2020, 220, 113097. [CrossRef]

69. Ferdous, S.; Bin Khaled, W.; Ahmed, B.; Salehin, S.; Ghani Ovy, E. Electric Vehicle with Charging Facility in Motion using Wind Energy. In Proceedings of the World Renewable Energy Congress, Linköping, Sweden, 8-13 May 2011; Volume 57, pp. 3629-3636. [CrossRef]

70. Goushcha, O.; Felicissimo, R.; Danesh-Yazdi, A.H.; Andreopoulos, Y. Exploring harnessing wind power in moving reference frames with application to vehicles. Adv. Mech. Eng. 2019, 11, 168781401986568. [CrossRef]

71. Hossain, M.F.; Fara, N. Integration of wind into running vehicles to meet its total energy demand. Energy Ecol. Environ. 2017, 2, 35-48. [CrossRef]

72. General Motors. 2019 Chevrolet Volt Brochure. Available online: https://www.chevrolet.ca/content/dam/chevrolet/na/ canada/english/index/download-a-brochure/02-pdfs/my19-cdn-volt-brochure-en.pdf (accessed on 1 December 2020).

73. BMW. BMW i3s REX Sport 2020. Available online: https://www.guideautoweb.com/en/makes/bmw/i3/2020/specifications/ s-rex/ (accessed on 1 December 2020).

74. BMW i3 (94 Ah) REX Dynamic Eléctrico 2017. Available online: https://www.bmw.com.mx/content/dam/bmw/ marketMX/bmw_com_mx/Descargas/Fichas-Tecnicas-2018/i3/FichaTécnicaBMWi3(94Ah)REXDynamic2017.pdf (accessed on 1 December 2020).

75. Leach, F.; Kalghatgi, G.; Stone, R.; Miles, P. The scope for improving the efficiency and environmental impact of internal combustion engines. Transp. Eng. 2020, 1, 100005. [CrossRef]

76. Menzel, G.; Hennings Och, S.; Cocco Mariani, V.; Mauro Moura, L.; Domingues, E. Multi-objective optimization of the volumetric and thermal efficiencies applied to a multi-cylinder internal combustion engine. Energy Convers. Manag. 2020, 216, 112930. [CrossRef]

77. Ouyang, T.; Zhao, Z.; Wang, Z.; Zhang, M.; Liu, B. A high-efficiency scheme for waste heat harvesting of solid oxide fuel cell integrated homogeneous charge compression ignition engine. Energy 2021, 229, 120720. [CrossRef]

78. Hahn, S.; Braun, J.; Kemmer, H.; Reuss, H.C. Optimization of the efficiency and degradation rate of an automotive fuel cell system. Int. J. Hydrogen Energy 2021. [CrossRef]

79. Hoeflinger, J.; Hofmann, P. Air mass flow and pressure optimisation of a PEM fuel cell range extender system. Int. J. Hydrogen Energy 2020, 45, 29246-29258. [CrossRef]

80. Toyota. Second Generation Toyota Mirai. Still Zero Emissions. Available online: https://www.toyota-europe.com/world-oftoyota/articles-news-events/2019/new-mirai-concept (accessed on 1 December 2020).

81. Hyundai NEXO de pila de combustible I Hyundai I Hyundai Motor España. Available online: https:/ /www.hyundai.com/es / modelos/nexo.html (accessed on 1 December 2020).

82. Nikola Two. Available online: https:/ / nikolamotor.com/two (accessed on 1 December 2020)

83. Taner, $\mathrm{T}$. The novel and innovative design with using $\mathrm{H}_{2}$ fuel of PEM fuel cell: Efficiency of thermodynamic analyze. Fuel 2021, 302, 121109. [CrossRef]

84. Ji, C.; Wang, H.; Shi, C.; Wang, S.; Yang, J. Multi-objective optimization of operating parameters for a gasoline Wankel rotary engine by hydrogen enrichment. Energy Convers. Manag. 2021, 229, 113732. [CrossRef]

85. Sadiq, G.A.; Al-Dadah, R.; Mahmoud, S. Development of rotary Wankel devices for hybrid automotive applications. Energy Convers. Manag. 2019, 202, 112159. [CrossRef]

86. Mazda 2 RE Range-Extender: Return of the Rotary-News-Car and Driver. Available online: https:/ /www.caranddriver.com/ news /a15366035/mazda-2-re-range-extender-return-of-the-rotary/ (accessed on 1 November 2020).

87. Martins, J.J.; Uzuneanu, K.; Ribeiro, B.S.; Jasasky, O. Thermodynamic Analysis of an Over-Expanded Engine. SAE Tech. Pap. 2004, 113, 476-490. [CrossRef]

88. Zhao, J.; Ma, Y.; Zhang, Z.; Wang, S.; Wang, S. Optimization and matching for range-extenders of electric vehicles with artificial neural network and genetic algorithm. Energy Convers. Manag. 2019, 184, 709-725. [CrossRef]

89. Zhang, J.; Li, Y.; Lv, C.; Yuan, Y. New regenerative braking control strategy for rear-driven electrified minivans. Energy Convers. Manag. 2014, 82, 135-145. [CrossRef]

90. Yang, Y.; He, Q.; Chen, Y.; Fu, C. Efficiency Optimization and Control Strategy of Regenerative Braking System with Dual Motor. Energies 2020, 13, 400-411. [CrossRef]

91. Duan, J.; Fan, S.; An, Q.; Sun, L.; Wang, G. A comparison of micro gas turbine operation modes for optimal efficiency based on a nonlinear model. Energy 2017, 134, 400-411. [CrossRef] 
92. Nicolosi, F.F.; Renzi, M. Effect of the Regenerator Efficiency on the Performance of a Micro Gas Turbine Fed with Alternative Fuels. Energy Procedia 2018, 148, 687-694. [CrossRef]

93. Ezzat, M.F.; Dincer, I. Development and exergetic assessment of a new hybrid vehicle incorporating gas turbine as powering option. Energy 2019, 170, 112-119. [CrossRef]

94. Ji, F.; Zhang, X.; Du, F.; Ding, S.; Zhao, Y.; Xu, Z.; Wang, Y.; Zhou, Y. Experimental and numerical investigation on micro gas turbine as a range extender for electric vehicle. Appl. Therm. Eng. 2020, 173, 115236. [CrossRef]

95. Barakat, A.A.; Diab, J.H.; Badawi, N.S.; Bou Nader, W.S.; Mansour, C.J. Combined cycle gas turbine system optimization for extended range electric vehicles. Energy Convers. Manag. 2020, 226, 113538. [CrossRef]

96. Fathabadi, H. Utilizing solar and wind energy in plug-in hybrid electric vehicles. Energy Convers. Manag. 2018, 156, 317-328. [CrossRef]

97. Fathabadi, H. Recovering waste vibration energy of an automobile using shock absorbers included magnet moving-coil mechanism and adding to overall efficiency using wind turbine. Energy 2019, 189, 116274. [CrossRef]

98. de Dios Javier Roldán, I.C.M. Meet Eolo, A Wind-Powered EV From Colombia. Available online: https://www.iamrenew. com/green-transportation/meet-eolo-wind-powered-ev-colombia/\#: :text=The \%20Eolo\%2C\%20Colombia's\%20only \%20 homegrown,it\%20is\%20powered\%20by\%20wind (accessed on 1 January 2021).

99. Boyes, J.D.; Clark, N.H. Technologies for energy storage flywheels and super conducting magnetic energy storage. In Proceedings of the 2000 Power Engineering Society Summer Meeting (Cat. No. 00CH37134), Seattle, WA, USA, 16-20 July 2000; Volume 3, pp. 1548-1550. [CrossRef]

100. Li, J.; Zhao, J. Energy recovery for hybrid hydraulic excavators: Flywheel-based solutions. Autom. Constr. 2021, 125, 103648. [CrossRef]

101. Erdemir, D.; Dincer, I. Assessment of Renewable Energy-Driven and Flywheel Integrated Fast-Charging Station for Electric Buses: A Case Study. J. Energy Storage 2020, 30, 101576. [CrossRef]

102. Wang, W.; Li, Y.; Shi, M.; Song, Y. Optimization and control of battery-flywheel compound energy storage system during an electric vehicle braking. Energy 2021, 226, 120404. [CrossRef]

103. Vazquez, S.; Lukic, S.M.; Galvan, E.; Franquelo, L.G.; Carrasco, J.M. Energy storage systems for transport and grid applications. IEEE Trans. Ind. Electron. 2010, 57, 3881-3895. [CrossRef]

104. Puddu, P.; Paderi, M. Hydro-pneumatic accumulators for vehicles kinetic energy storage: Influence of gas compressibility and thermal losses on storage capability. Energy 2013, 57, 326-335. [CrossRef]

105. Chen, B.; Yousif, A.A.; Riley, P.H.; Hann, D.B. Development and Assessment of Thermoacoustic Generators Operating by Waste Heat from Cooking Stove. Engineering 2012, 04, 894-902. [CrossRef]

106. Backhaus, S.; Swift, G.W. A thermoacoustic-Stirling heat engine: Detailed study. J. Acoust. Soc. Am. 2000, 107, 3148-3166. [CrossRef]

107. Mumith, J.A.; Makatsoris, C.; Karayiannis, T.G. Design of a thermoacoustic heat engine for low temperature waste heat recovery in food manufacturing: A thermoacoustic device for heat recovery. Appl. Therm. Eng. 2014, 65, 588-596. [CrossRef]

108. Blanc-benon, P.; Jondeau, E.; Comte-Bellot, G. Analysis of the acoustic field in a thermoacoustic system using time-resolved particle image velocimetry and constant-voltage anemometry. In Proceedings of the 3rd International Workshop on Thermoacoustics, Enschede, The Netherlands, 26-27 October 2015.

109. Khoshnoud, F.; Zhang, Y.; Shimura, R.; Shahba, A.; Jin, G.; Pissanidis, G.; Chen, Y.K.; De Silva, C.W. Energy Regeneration from Suspension Dynamic Modes and Self-Powered Actuation. IEEE/ASME Trans. Mechatron. 2015, 20, 2513-2524. [CrossRef]

110. Li, Z.; Zuo, L.; Luhrs, G.; Lin, L.; Qin, Y.X. Electromagnetic energy-harvesting shock absorbers: Design, modeling, and road tests. IEEE Trans. Veh. Technol. 2013, 62, 1065-1074. [CrossRef]

111. Maravandi, A.; Moallem, M. Regenerative shock absorber using a two-leg motion conversion mechanism. IEEE/ASME Trans. Mechatron. 2015, 20, 2853-2861. [CrossRef]

112. Electric Vehicle Range Extender Market Forecast Report, 2018-2025. Available online: https://www.marketsandmarkets.com/ Market-Reports/electric-vehicle-range-extender-market-208131566.html (accessed on 1 July 2021).

113. Electric Vehicle (EV) Range Extender Market Statistics, Trends, Demand, Size by 2026. Available online: https://www. alliedmarketresearch.com/electric-vehicle-range-extender-market-A06026 (accessed on 1 July 2021).

114. Electric Vehicle Range Extender Market to Witness 10.2\% CAGR By 2025 Owing to Rising Usage of Commercial \& Fully Electric Passenger Vehicles to Lower $\mathrm{CO}_{2}$ Emissions I Million Insights. Available online: https: / www.prnewswire.com/news-releases / electric-vehicle-range-extender-market-to-witness-10-2-cagr-by-2025-owing-to-rising-usage-of-commercial--fully-electricpassenger-vehicles-to-lower-co2-emissions--million-insights-301220939.html (accessed on 1 July 2021).

115. 2021 Honda Clarity Plug-In Hybrid-The Versatile Hybrid I Honda. Available online: https:/ /automobiles.honda.com/clarityplug-in-hybrid (accessed on 1 July 2021).

116. Mack Trucks to Evaluate Wrightspeed Route Powertrain in Mack LR Model I Mack Trucks. Available online: https://www. macktrucks.com/mack-news/2016/mack-trucks-to-evaluate-wrightspeed-route-powertrain-in-mack-lr-model/ (accessed on 1 July 2021).

117. Rover, L. Quarterly Light-Vehicle-Q1 2021. 2021. Available online: https://www.coxautoinc.com/wp-content/uploads/2021/0 4/Q1.Kelley-Blue-Book-Electrfication-Deck-2021.revised-4.26.pdf (accessed on 1 July 2021).

118. Sales, Q.; Ev, B. Electrified-Vehicle 2021. pp. 1-5. Available online: https://www.coxautoinc.com/wp-content/uploads/2021/0 1/Kelley-Blue-Book-Salesand-Data-Report-for-2020-Q4.pdf (accessed on 1 July 2021). 
119. Masclans Abelló, P.; Medina Iglesias, V.; de los Santos López, M.A.; Álvarez-Flórez, J. Real drive cycles analysis by ordered power methodology applied to fuel consumption, $\mathrm{CO}_{2}, \mathrm{NO}_{x}$ and $\mathrm{PM}$ emissions estimation. Front. Environ. Sci. Eng. 2021, 15, 4. [CrossRef]

120. Lee, D.; Park, G.; Son, B.; Jung, H. Efficiency improvement of IPMSG in the electric power generating system of a range-extended electric vehicle. IET Electr. Power Appl. 2019, 13, 943-950. [CrossRef]

121. Han, K.; Nguyen, T.W.; Nam, K. Battery energy management of autonomous electric vehicles using computationally inexpensive model predictive control. Electronics 2020, 9, 1277. [CrossRef]

122. Hu, X.; Zhang, X.; Tang, X.; Lin, X. Model predictive control of hybrid electric vehicles for fuel economy, emission reductions, and inter-vehicle safety in car-following scenarios. Energy 2020, 196, 117101. [CrossRef]

123. Fathy, H.; Reyer, J.; Papalambros, P.; Ulsov, A. On the coupling between the plant and controller optimization problems. In Proceedings of the 2001 American Control Conference. (Cat. No.01CH37148), Arlington, VA, USA, 25-27 June 2001; Volume 3, pp. 1864-1869. [CrossRef]

124. Silvas, E.; Hofman, T.; Murgovski, N.; Etman, P.; Steinbuch, M. Review of Optimization Strategies for System-Level Design in Hybrid Electric Vehicles. IEEE Trans. Veh. Technol. 2016, 66. [CrossRef]

125. Allison, J.T.; Herber, D.R. Special Section on Multidisciplinary Design Optimization: Multidisciplinary Design Optimization of Dynamic Engineering Systems. AIAA J. 2014, 52, 691-710. [CrossRef] 